\title{
THE NEGLIGENT COMMERCIAL TRANSACTION TORT: IMPOSING COMMON LAW LIABILITY ON MERCHANTS FOR SALES AND LEASES TO "DEFECTIVE" CUSTOMERS
}

\section{The EXPANDING Limits of Business LiabiLity}

Courts have described tort law as a sensitive balance between two opposing goals: coinpensating a plaintiff for injuries inflicted by another, ${ }^{1}$ and limiting a tortfeasor's liability to something less than the infinite consequences of his tortious act. ${ }^{2}$ Tort law involves a combination of statutory and common law; however, some jurists have asserted that the "development of the law of torts is peculiarly a function of the judiciary." 3 That philosophy has led to judicial legislation in areas of tort law traditionally shaped by statute. ${ }^{4}$ Specifically, several courts have imposed judge-made tort hability on businesses for transactions involving the sale or lease of nondefective products 5 to "incompetent" or "inexperienced" users. ${ }^{6}$

This new tort, which this Note labels "neghigent commercial transactions," arises when (1) a nierchant negligently sells or leases a product (2) to a youthful, incompetent, or inexperienced user (3) who the nierchant knows or should know is incoinpetent or inexperienced in the product's use, and (4) the sold or leased product proximately causes in-

1. See, e.g., Dillon v. Legg, 68 Cal. 2d 728, 739, 441 P.2d 912, 919, 69 Cal. Rptr. 72,79 (1968) (" $[W]$ e cannot let the difficulties of adjudication frustrate the principle that there be a remedy for every substantial wrong.").

2. See, e.g., In re Kinsman Transit Co., 338 F.2d 708, 725 (2d Cir. 1964) ("Somewhere a point will be reached when courts will agree that the link has become too tenuous-that what is claimed to be consequence is only fortuity."), cert. denied, 380 U.S. 944 (1965).

3. Brigance v. Velvet Dove Restaurant, Inc., 725 P.2d 300, 303 (Okla. 1986).

4. See, e.g., Rappaport v. Nichols, 31 N.J. 188, 156 A.2d 1 (1959). In Rappaport, the New Jersey Supreme Court held that an illegal sale of liguor to a minor (and, the court said in dicta, to an intoxicated person) under circumstances in which the seller should have known that the buyer was underage (or drunk) constitutes negligence. Id. at 202,156 A.2d at 9. The court reasoned that in the absence of a civil liability statute in New Jersey, imposing cominon law dram shop liability for sales of alcohol to minors and intoxicated persons "will strengthen and give greater force to the enhightened [criminal] statutory and regulatory precautions against such sales and their frigltening consequences." Id. at 205, 156 A.2d at 10. The court reached its result even though the New Jersey legislature had repealed the Prohibition-era statutes that had imposed strict liability for damages flowing froin illegal sales. See 1932 N.J. Laws 453-54 (repealing Act of Mar. 29, 1921, 1921 N.J. Laws 184); 1934 N.J. Laws 83, 104 (repealing Act of Mar. 17, 1922, 1922 N.J. Laws 628).

5. "Products," as used in this Note, refers to goods sold or leased in commercial transactions; the term does not refer to services.

6. See infra notes $91-94$ and accompanying text. 
jury to the customer's innocent employees or other third persons. ${ }^{7}$ The negligent commercial transaction tort is distinguishable from other torts involving commercial transactions in that it ignores issues of product liability and design defect, ${ }^{8}$ and it may lead to liability whether or not the transaction at issue is statutorily proscribed. ${ }^{9}$ Moreover, the neghigent commercial transaction tort is unusually potent. In states such as California and Missouri, judges have granted relief to injured third parties far removed from the commercial transactions that preceded the third parties' actionable injuries. ${ }^{10}$

The negligent commercial transaction tort has found mcreasing judicial acceptance principally because of an imaginative tactic im personal injury litigation. Plaintiffs have learned to overcome restrictive principles of recovery, such as respondeat superior and workers' compensation, by arguing for an extension of the policies underlying statutory prohibition of certain business transactions. ${ }^{11}$ For example, a plaintiff might argue that a state law proscribing the sale of gnns to minors is logically designed to prevent merchants from selling weapons to any immature

7. See, e.g., Dillon v. Suburban Motors, Inc., 166 Cal. App. 3d 233, 212 Cal. Rptr. 360, 365-66 (opinion omitted from California Appellate Reports at California Supreme Court's direction) (recognizing common law right of action against dealership that sold car to unlicensed 17-year-old), dismissed as moot, 705 P.2d 1260, 218 Cal. Rptr. 584 (1985) (en banc); Henderson Bros. Stores v. Smiley, 120 Cal. App. 3d 903, 918-20, 174 Cal. Rptr. 875, 883-84 (1981) (discussing elements of common law cause of action in suit by owner of damaged warehouse against merchant who sold tar kettle, which later exploded, to roofing contractor); Johnson v. Casetta, 197 Cal. App. 2d 272, 27374, 17 Cal. Rptr. 81, 82-83 (1961) (seminal case recognizing common law right of action against used-car dealer who sold car to unlicensed and incompetent driver); Fowler v. Park Corp., 673 S.W.2d 749, 761 (Mo. 1984) (en banc) (Donnelly, J., dissenting) (setting out necessary elements of tort claim against railroad yard owner for negligently leasing railroad engine to tenant); Barsness v. General Diesel \& Equip. Co., 383 N.W.2d 840, 842 (N.D. 1986) (upholding injured construction worker's common law claim against lessor of construction equipment for negligently leasing crane to inexperienced operator).

8. See, e.g., Vic Potamkin Chevrolet, Inc. v. Horne, 505 So. 2d 560, 562 (Fla. Dist. Ct. App. 1987) (no allegation that "negligently" sold car was defective), aff'd, No. 70,499, slip op. (Fla. Sept. 1, 1988) (Westlaw, 1988 WL 93694); see also White v. Chrysler Corp., 421 Mich. 197, 198, 364 N.W.2d 619, 621 (1984) (employee's negligent entrustment action for damages after hands crushed by power-press dies not based on defective design or manufacture, although inherent danger of product considered); Fredericks v. General Motors Corp., 411 Mich. 712, 720, 311 N.W.2d 725, 728 (1981) (products liability pleaded as alternative to negligent entrustment).

9. See, e.g., Roland v. Golden Bay Chevrolet, 161 Cal. App. 3d 102, 207 Cal. Rptr. 413 (1984) (opinion omitted from California Appellate Reports) (upholding cause of action against car dealer for selling vehicle to allegedly incompetent driver, although sale violated no statute), dismissed as moot, 704 P.2d 175, 217 Cal. Rptr. 415 (Cal. 1985) (en banc).

10. See, e.g., Dillon, 212 Cal. Rptr. at 363-64 (automobile accident occurred weeks after sale); Fowler, 673 S.W.2d at 751 (injury occurred eight days after entrustment of railroad engine).

11. Cf. Woods, Negligent Entrustment Revisited: Developments 1966-76, 30 ARK. L. REv. 288 (1976) (discussing extension of doctrine generally, and specifically in relation to respondeat superior). 
person. ${ }^{12}$ This approach allows some plaintiffs to avoid traditional barriers against recovery ${ }^{13}$ and thus tap into the deeper pockets of American business. ${ }^{14}$ So far, neghigent commercial transaction suits have targeted the sellers or lessors of tar kettles, ${ }^{15}$ construction cranes, ${ }^{16}$ railroad engines, ${ }^{17}$ gasoline, ${ }^{18}$ and automobiles ${ }^{19}$ that have caused injury to persons other than buyers or lessees.

This Note will discuss the development of the neghigent commercial transaction tort in light of recent judicial interpretation of section 390 of the Restatement (Second) of Torts, which defines the tort known as "negligent entrustment";20 the common law precedent of dram shop liability; ${ }^{21}$ and the judicial perception that many injured plaintiffs deserve more compensation than traditional legal theories offer. ${ }^{22}$ The Note will

12. See, e.g., Angell v. F. Avanzini Lumber Co., 363 So. $2 d 571$ (Fla. Dist. Ct. App. 1978). In Angell, a gun dealer sold a rifie to an adult female who had behaved oddly and unsafely while im the store. Shortly after the sale, the woman used the weapon to kill someone. The administratrix of the decedent's estate unsuccessfully attempted to state a cause of action against the gun dealer under Fla. STAT. ANN. $\S 790.17$ (West 1976), which proscribes sales of weapons to minors and persons of unsound mind. The court, notwithstanding the failure of the statutory claim, recoguized a cominon law action against the dealer for negligently selling the gun. 363 So. $2 \mathrm{~d}$ at 572 .

13. See infra notes 49-55 and accompanying text (discussing respondeat superior); infra notes 57-70 and accompanying text (discussing workers' compensation).

14. Cf. Love v. New York Timies Co., 691 F.2d 261, 262 (6th Cir. 1982) (would-be publisher, who failed to launch a magazine, tries to recoup financial losses from deep pocket of innocent pubhisher); Monroe v. Interlock Steel Co., 128 Misc. 2d 28, 30, 487 N.Y.S.2d 1013, 1015 (Sup. Ct. 1985) (plaintiff sues successor corporation because, as court indicated, "the once deep pockets of the sole proprietor have, in all likelihood, been emptied into the now deep, but secure, pockets of the successor corporation").

15. Henderson Bros. Stores v. Smiley, 120 Cal. App. 3d 903, 174 Cal. Rptr. 875 (1981) (owner of damaged warehouse sues seller of tar kettle for selling to allegedly incompetent roofing contractor).

16. Barsness v. General Diesel \& Equip. Co., 383 N.W.2d 840 (N.D. 1986) (suit by injured construction worker against company that leased crane to imexperienced operator).

17. Fowler v. Park Corp., 673 S.W.2d 749 (Mo. 1984) (en banc) (suit by railroad car sandblaster against lessor of switch engine who leased to inexperienced operator).

18. O'Toole v. Carlsbad Shell Serv. Station, 202 Cal. App. 3d 151, 247 Cal. Rptr. 663, 671 (ordered not published in California Appellate Reports; opimon appears in Californio Reporter advance sheets) (owner of gas station that sold gasoline to clearly intoxicated driver may be held liable for deaths caused in subsequent collision), review denied, [no docket number] (Cal. Aug. 18, 1988) (LEXIS, 1988 Cal. LEXIS 220); Roberts v. Shop \& Go, Inc., 502 So. 2d 915 (Fla. Dist. Ct. App. 1986) (suit by victims, burned when gasolime purchaser threw and ignited gasoline, against convenience store that sold gasoline).

19. Roland v. Golden Bay Chevrolet, 161 Cal. App. 3d 102, 207 Cal. Rptr. 413 (1984) (opimion omitted from California Appellate Reports) (suit by plaintiff, injured in ear accident with unlicensed reckless driver, against dealership that sold car to driver), dismissed as moot, 704 P.2d 175, 217 Cal. Rptr. 415 (Cal. 1985) (en banc); Tosh v. Scott, 129 Ill. App. 3d 322, 472 N.E.2d 591 (1984) (suit against father who sold automobile to his son).

20. See RESTATEMENT (SECOND) OF TORTS $§ 390$ (1965); infra notes 31-44 and accompanying text. The Restatement (Second) does not use the term "negligent entrustment."

21. See infra notes $71-85$ and accompanying text.

22. See infra notes $62-64$ and accompanying text. 
then analyze cases that have considered the tort.. ${ }^{23}$ Lastly, the Note will argue for judicial restraint in extending businesses' liability beyond linnits already established by statute, ${ }^{24}$ noting that in the course of compensating plaintiffs, courts can unwittingly impose unreasonable and uncertain duties on industries competing in American markets. Tlese uncertain judge-made duties can, in turn, lrave an adverse impact on the national econoiny. ${ }^{25}$

\section{Negligence Involving the Sale or Lease of Goods}

The negligent commercial transaction tort las long existed in American law as a cause of action for injuries that arise from sales in violation of criminal statutes. ${ }^{26}$ In the early twentieth century, statutes proscribed the sale or lease of such products as guns, ${ }^{27}$ explosives, ${ }^{28}$ and alcohol ${ }^{29}$ to individuals not lawfully einpowered to possess thein. A violation of these statutes constituted negligence or a breach of duty; third parties injured by such illegally sold or leased products could recover damages from the merchants who had conducted the transactions. ${ }^{30}$ Today, however, even

23. See infra notes 91-162 and accompanying text.

24. See infra notes 166-89 and accounpanying text.

25. See infra notes 163-77 and accoinpanying text.

26. See, e.g., Anderson v. Settergren, 100 Minn. 294, 295-97, 111 N.W. 279, 279-80 (1907) (defendant negligently sold cartridges, in violation of statute, to 13-year-old boy who recklessly injured plaintiff); Driesse v. Verblaauw, 9 N.J. Misc. 173, 173, 176, 153 A. 388, 388-89, 390 (1931) (employee negligently sold rifle cartridges, in violation of statute, to 15-year-old boy who killed friend during horseplay); Neff Lumber Co. v. First Nat'l Bank, 122 Ohio St. 302, 304, 307, 171 N.E. $327,328,329$ (1930) (defendant's clerk negligently sold shotguu, in violation of statute, to minor who wounded plaintiffs); Bernard v. Smith, 36 R.I. 377, 379, 90 A. 657, 658 (1914) (defendant storeowner negligently sold 22-caliber rifie and cartridges, in violation of statute, to 11-year-old boy who shot plaintiff in the arm); see also Comment, Liability of Commercial Vendors, Employers, and Social Hosts for Torts of the Intoxicated, 19 WAKE FOREST L. REv. 1013, 1015 (1983) (post-Civil War dram shop acts established civil causes of action against liquor vendors for injuries to third parties resulting from illegal sales of alcohol to minors, habitual druuks, or the obviously intoxicated).

27. E.g., ARIz. REv. STAT. ANN. § 13-3102(5) (1982) (originally enacted in 1901, statute proscribes "[s]elling or transferring a deadly weapon to a prohibited possessor"); N.C. GEN. STAT. § 14315 (1987) (originally enacted iu 1893, statute proscribes sale of guns and other weapons to ininors).

28. E.g., GA. CODE ANN. \& 25-1-1 (1982) (enacted in 1958, statute prohibits sale of blasting caps to minors); MASS. GEN. L. ch. 148, $\S 16$ (1986) (originally enacted in 1904, statute prohibits sale of explosives to nonlicensed individuals); N.Y. LAB. LAw § 458(11) (McKinney 1986) (originally enacted in 1949, statute proscribes sales of explosives to persons under 18 years old).

29. E.g., CAL. Bus. \& Prof. CODE $\$ 25,602$ (a) (West 1987) (originally enacted in 1935, statute proscribes sales of alcohol to drunks or obviously intoxicated people); CoNN. GEN. STAT. $§ 30-86$ (1987) (originally enacted in 1935, statute prohibits sales of alcohol to ininors or drunks).

30. See, e.g., Hetherton v. Sears, Roebuck \& Co., 593 F.2d 526, 529-30 (3d Cir. 1979) (sale of ammunition in violation of Delaware statute constitutes negligence per se); Holzer, Liability to the Injured Third Party for Negligent Entrustment of a Firearm, 59 CHI. B. REC. 346, 347 (1978) (knowing violation of Illinois gun control statute, which proscribes sale of firearms to desiguated groups of individuals, constitutes breach of specific duty and gives rise to cause of action in negligence). In the 
in the absence of statutory proscriptions, courts are creating broad coinmon law duties for businesses to select appropriate customers.

\section{A. The Expanding Doctrine of "Negligent Entrustment."}

Sections 308 and 390 of the Restatement (Second) of Torts outline the tort of "neghigent entrustment." 31 The doctrine of negligent entrustment predates the publication of the first Restatement of Torts ${ }^{32}$ and to-

interest of public safety, courts have recognized that the duty to investigate buyers of inherently dangerous instrunnentalities is a reasonable requireinent for doing business. See, e.g., Hetherton v. Sears, Roebuck \& Co., 652 F.2d 1152, 1160 (3d Cir. 1981) ("As a deterrent to our nation's escalating violence, certainly a legislature inay prohibit the sale of handguns to individuals who have records ... and certainly they can impose substantial civil liability on gnn sellers like Sears who breach statutory obligations.").

31. See REstatement (SECOND) OF TORTS $\S \S 308,390$ (1965). Section 308 of the Restatement (Second), entitled "Permitting Improper Persons to Use Things or Engage in Activities," states:

It is negligence to permit a third person to use a thing or to engage in an activity which is under the control of the actor, if the actor knows or should know that such person intends or is likely to use the thing or to conduct himself in the activity in such a manner as to create an unreasonable risk of harm to others.

Id. $\S 308$.

Section 390, entitled "Chattel for Use by Person Known to be Incompetent," states:

One who supplies directly or through a third person a chattel for the use of another whom the supplier knows or lias reason to know to be likely because of his youth, inexperience, or otherwise, to use it in a manner involving unreasonable risk of physical harm to himself and others whoin the supplier should expect to share in or be endangered by its use, is subject to liability for physical harm resulting to them.

Id. $\S 390$. Section 390 is described as a "special apphication" of section 308. Id. $\S 390$ comment a. Courts have repeatedly held that the necessary elements of a negligent entrustinent clain include:

(1) Proof that the entrustee was incoinpetent, inexperienced or reckless; (2) that the entrustor "knew or had reason to know" of the entrustee's condition or proclivities; (3) that there was an entrustment of the chattel; (4) that the entrustment created an appreciable risk of harm to the plaintiff and a relational duty on the part of the defendant; (5) that the harm to the plaintiff was "proximately" or "legally" caused by the negligence of the defendant.

Woods, Negligent Entrustment: Evaluation of a Frequently Overlooked Source of Additional Liability, 20 ARK. L. REv. \& B. Ass'N J. 101, 101-02 (1966) (footnotes oinitted), quoted in Collins v. Arkansas Ceinent Co., 453 F.2d 512, 514 (8th Cir. 1972), and in Evans v. Allen Auto Rental \& Truck Leasing, 555 S.W.2d 325, 326 (Mo. 1977); see also Chiniche v. Sinith, 374 So. 2d 872, 876 (Ala. 1979) (requiring similar elements); Williams v. Steves Indus., 699 S.W.2d 570, 571 (Tex. 1985) (same).

Maryland has generally led in the developinent of negligent entrustinent doctrine, particularly in the area of motor velicie torts. See, e.g., Curley v. General Valet Serv., 270 Md. 248, 259-65, 311 A.2d 231, 237-40 (1973) (discussing doctrine's developinent in Maryland caselaw); Snowhite v. State, 243 Md. 291, 311-15, 221 A.2d 342, 353-56 (1966) (same); Rounds v. Phillips, 168 Md. 120, 126-27, 177 A. 174, 176-77 (1935) (first case applying doctrine). The doctrine also has strong support in Alabama. See Keller v. Kiedinger, 389 So. 2d 129, 132 (Ala. 1980) (citing Note, Negligent Entrustment in Alabama, 23 ALA. L. REV. 733 (1971)).

32. See, e.g., Gardiner v. Soloinon, 200 Ala. 115, 117, 75 So. 621, 623 (1917) (mother who knew of aduit son's incompetence may be held liable for permitting hiun to drive car); Allen v. Bland, 168 S.W. 35, 39-40 (Tex. Civ. App. 1914) (father may be held liable for entrusting automobile to 11year-old son); Crowell v. Duncan, 145 Va. 489, 508-11, 134 S.E. 576, 581-82 (1926) (father liable for entrusting automobile to habitually intoxicated son). 
day affords a civil cause of action in virtually every state. ${ }^{33}$ The doctrine allows a third party to recover damages from a party who "entrusts" goods to a user if the user injures the third party through inexperience or incompetence in handling the goods. ${ }^{34}$ The willingness of some courts to include virtually any product involved in commercial sales and leases within the scope of negligent entrustınent, ${ }^{35}$ along with the refusal of other courts to distinguish between a "user" of a product and a "buyer" of a product, ${ }^{36}$ has fostered developinent of the neghigent commercial transaction tort. ${ }^{37}$

1. Negligent Entrustment Principles as Applied to Sales and Leases. It is helpful to think of the negligent cominercial transaction doctrine as a "commercial subset" of the inore general doctrine of neghigent entrustment. Both torts are associated with sections 308 and 390 of the Restatement (Second) of Torts. ${ }^{38}$ Their application differs only in that neghigent entrustment usually targets entrusters, such as lenders, donors, or bailors, while the negligent commercial transaction tort targets sellers and

Early court decisions generally interpreted the original Restatement to prevent the inposition of negligent entrustment liability on sellers. See, e.g., Perez v. G \& W Chevrolet, Inc., 274 Cal. App. 2d 766, 767-69, 79 Cal. Rptr. 287, 288-90 (1969) (dismissing parents' wrongful death action against seller of car to unlicensed and inexperienced 19-year-old who killed herself driving two weeks later); Fuller v. Standard Stations, Inc., 250 Cal. App. 2d 687, 58 Cal. Rptr. 792 (1967) (dismissing accident victim's action against service station that sold gasoline to intoxicated driver who injured plaintiff and killed four fainily members in collision); Tharp v. Monsees, 327 S.W.2d 889 (Mo. 1959) (dismissing father's action against seller of gasoline to 12-year-old son burned when gasoline ignited during horseplay); Rush v. Smitherman, 294 S.W.2d 873 (Tex. Civ. App. 1956) (dismissing wrongful death action against dealer for selling car to unlicensed buyer who killed plaintiffs' father in collision).

33. Douglas v. Hartford Ins. Co., 602 F.2d 934, 936 (10th Cir. 1979) ("Negligent entrustment is a common law tort, recognized in virtually every state.").

34. RESTATEMENT (SECOND) OF TORTS $\$ \S 308,390$ (1965).

35. Cf. Brown v. Vanity Fair Mills, Inc., 291 Ala. 80, 83, 277 So. 2d 893, 896 (1973) (noting that "the all-embracing term 'chattels' used in the Restateinent is not restricted to autoinobiles").

36. See, e.g., O'Toole v. Carlsbad Shell Serv. Station, 202 Cal. App. 3d 151, 247 Cal. Rptr. 663 (ordered not published in California Appellate Reports; opinion appears in California Reporter advance sheets) ("supply" of gasoline by service station to drnnk driver), review denied, [no docket number] (Cal. Aug. 18, 1988) (LEXIS, 1988 Cal. LEXIS 200); $c f . R u s h, 294$ S.W.2d at 875 (holding RESTATEMENT OF TORTS $\S 390$ (1934) inapplicable to automobile buyers).

37. See, e.g., Dillon v. Suburban Motors, Inc., 166 Cal. App. 3d 233, 212 Cal. Rptr. 360 (opinion omitted froin California Appellate Reports at California Supreme Court's direction) (recognizing common law action against dealership that sold car to unlicensed 17-year-old), dismissed as moot, 705 P.2d 1260, 218 Cal. Rptr. 584 (Cal. 1985) (en banc); Barsness v. General Diesel \& Equip. Co., 383 N.W.2d 840 (N.D. 1986) (applying REsTATEMENT (SECOND) OF TORTs $§ 390$ to uphold injured construction worker's cominon law negligence action against coinpany that leased crane to "inexperienced" customer).

38. See supra note 31 and accompanying text; see also RESTATEMENT (SECOND) OF TORTS $\S 390$ comment a ("The rule stated applies to anyone who supplies a chattel for the use of another[,] ... [including] sellers, lessors, donors or lenders, and . . . all kinds of bailors . . . ."). 
lessors. ${ }^{39}$ In fact, the Restatement (Second) of Torts indiscriminately apphies the doctrine to all "suppliers" of goods, providing no technical definition of the term "supplier." 40

The substantive difference between the negligent commercial transaction and negligent entrustment torts stems froin the failure of the first Restatement of Torts to state explicitly whether sections 308 or 390 applied to seliers and lessors. ${ }^{41}$ This omission initially prompted some courts to interpret the sections conservatively and to exclude merchants from liability. ${ }^{42}$ Recently, however, the revised language of section 390 of the Restatement (Second) of Torts ${ }^{43}$ has inspired the developinent of a civil cause of action that applies to both sellers and lessors of products. ${ }^{44}$

2. How Negligent Entrustment Sidesteps Traditional Obstacles to Recovery. In the past, courts have generally limited the reach of the negligent entrustment doctrine to cases involving autoinobiles or mlierently dangerous instrumentalities. ${ }^{45}$ Today, however, more and more courts are adopting the view that the doctrine's application "does not

39. Cf. Vic Potamkin Chevrolet, Inc. v. Horne, 505 So. 2d 560, 561-62 (Fla. Dist. Ct. App. 1987) (distinguishing between negligent loan or bailment situations and negligent sales), aff'd, No. 70,499, slip op. (Fla. Sept. 1, 1988) (Westlaw, 1988 WL 93694). Compare Hartford Accident \& Indem. Co. v. Abdullah, 94 Cal. App. 3d 81, 156 Cal. Rptr. 254 (1979) (negligent entrustment action against owner of loaned automobile) with Barsness, 383 N.W.2d at 840 (negligent entrustment action against lessor of crane).

40. RESTATEMENT (SECOND) OF TORTS $\S 390$ comment a.

41. See Restatement OF Torts $\$ \S 308,390$ (1934).

42. See, e.g., Tharp v. Monsees, 327 S.W.2d 889, 895 (Mo. 1959) (first Restatement's language does not apply to sale of gasoline to minors); Rush v. Smitlerman, 294 S.W.2d 873, 875 (Tex. Civ. App. 1956) (same language does not include sellers of automobiles).

43. See supra notes 31, 38.

44. See, e.g., Dillon v. Suburban Motors, Inc., 166 Cal. App. 3d 233, 212 Cal. Rptr. 360 (opinion omitted from California Appellate Reports at California Supreme Court's direction) (cause of action exists for negligent sale of automobile), dismissed as moot, 705 P.2d 1260, 218 Cal. Rptr. 584 (1985) (en banc); Barsuess v. General Diesel \& Equip. Co., 383 N.W.2d 840 (N.D. 1986) (cause of action exists for negligent lease of construction crane); $c f$. Vic Potamkin Clievrolet, Iuc. v. Horne, 505 So. 2d 560, 561 (Fla. Dist. Ct. App. 1987) ("The issue presented on appeal is wliether this court should extend the law of negligeut entrustment to iuclude negligent sales."), aff'd, No. 70,499, slip op. (Fla. Sept. 1, 1988) (Westlaw, 1988 WL 93694).

45. Early cases involving eutrustment of inlierently dangerous instrumentalities include McEldon v. Drew, 138 Iowa 390, 116 N.W. 147 (1908) (gunpowder sold to 12-year-old boy); Bosserman v. Smitl, 205 Mo. App. 657, 226 S.W. 608 (1920) (fireworks sold to clinldren); Gerbiuo v. Greenhut-Siegel-Cooper Co., 165 A.D. 763, 152 N.Y.S. 502 (1915) (airgun entrusted to minor); Bernard v. Smith, 36 R.I. 377, 90 A. 657 (1914) (rifle sold to 11 -year-old boy). See generally 1 J. Dooley, Modern Tort LAW $\S 23.01$ (1982); W. Prosser \& W. Keeton, The Law of TorTs $\S 33$, at $200, \S 73$, at 522-24 (5tli ed. 1984); Holzer, supra note 30 , at 352 .

For au example of low courts traditionally treated the issue of negligent eutrnstment of automobiles, see Gardiner v. Solomon, 200 Ala. 115, 117, 75 So. 621, 623 (1917) (parent may be held liable for entrusting automobile to reckless adult son); Sanders v. Walden, 214 Ark. 523, 526-27, 217 S.W.2d 357, 359 (1949) (car entrusted to brother, who was four feet, two inclies tall); Owens v. Carmichael's U-Drive Autos, 116 Cal. App. 348, 2 P.2d 580 (1931) (car rented to unaccompanied 
depend on the nature of the chattel." 46 These courts argue that the analysis should focus on the incoinpetence or inexperience of the user and the supplier's knowledge of that ineptitude. ${ }^{47}$

Much of the modern popularity of the negligent entrustment doctrine-and of the narrower neghigent commercial transaction tort-stems froin its usefulness in overcommg well-settled limitations to tort recovery under workers' compensation statutes ${ }^{48}$ and the theory of respondeat superior. ${ }^{49}$ Respondeat superior allows third-party recovery against employers only when neghigent employees act within their "scope of employment"; only then are employees considered agents of their employers. ${ }^{50}$ Workers' compensation statutes likewise allow injured employees to recover damages against their employers only for "workconnected injuries." 51 These theories limit recovery to the employment context, and as a result third parties and employees injured by a negligent employee acting outside the scope of employment normally cannot recover damages against the employer. ${ }^{52}$

adult possessing only student permit); Golembe v. Blumberg, 262 A.D. 759, 27 N.Y.S.2d 692 (1941) (upholding action against father for giving car to epileptic son).

46. Moning v. Alfono, 400 Mich. 425, 445 n.24, 254 N.w.2d 759, 768 n.24 (1977) (slingshot); see also Pritchett v. Kimberling Cove, Inc., 568 F.2d 570 (8th Cir. 1977) (boats), cert. denied, 436 U.S. 922 (1978); Brown v. Vanity Fair Mills, Inc., 291 Ala. 80, 83, 277 So. 2d 893, 896 (1973) (tools); Meister v. Fisher, 462 So. 2d 1071 (Fla. 1984) (golf carts); Fredericks v. General Motors Corp., 411 Mich. 712, 311 N.W.2d 725 (1981) (drill-press dies).

47. See, e.g., Drummond v. Walker, 643 F. Supp. 190, 191 (D.D.C. 1986); Herbert v. Whittle, 69 Md. App. 273, 279, 517 A.2d 358, 362-68 (1986), cert. denied, 309 Md. 49, 522 A.2d 393 (1987); Fredericks, 411 Mich. at 719, 311 N.W.2d at 727; Denby v. Davis, 212 Va. 836, 838-39, 188 S.E.2d 226, 229 (1972).

48. See infra notes 57-70 and accompanying text (discussing workers' compensation); see also Woods, supra note 31, at 120 (suit grounded in negligent entrustment can avoid fatal defenses and allow for broader admissibility of evidence).

49. The phrase means "let the master answer." The respondeat superior doctrine makes a master vicariously liable in tort for her servant's wrongful acts that injure third parties. See generally RESTATEMENT (SECOND) OF AGENCY $\$ 219$ (1957); 1 J. DOOLEY, supra note 45, ch. 16; W. Prosser \& W. KEETON, supra note $45, \S \S 69-70$.

50. See, e.g., Abraham v. S.E. Onorato Garages, 50 Haw. 628, 632, 446 P.2d 821, 825 (1968); McNeill v. Spindler, 191 Va. 685, 694-96, 62 S.E.2d 13, 17-18 (1950); see also Woods, supra note 11, at 294-99. For an explanation of the limitations of respondeat superior, see RESTATEMENT (SECoND) OF AGENCY §§ 219, 228 (1957); W. Prosser \& W. KeEton, supra note 45, §70.

51. 1 A. LaRson, The Law of Workmen's Compensation $\$ 2.10$ (1987).

52. Id.; W. Prosser \& W. KeEToN, supra note 45, § 70, at 501; see, e.g., Brown v. Vanity Fair Mills, Inc., 291 Ala. 80, 82, 277 So. 2d 893, 895 (1973) (plaintiff could not recover against employer of person who struck him in the head with a hammer because complaint did not allege that person was acting within scope of employment); Mullins v. Harrell, 490 So. 2d 1338, 1339 (Fla. Dist. Ct. App. 1986) (employer not liable for truck damage caused by employee because employee was using truck on personal errand outside scope of employment); $c f$. Collins v. Arkansas Cement Co., 453 F.2d 512, 514 (8th Cir. 1972) ("Since [the employee] admittedly was not within the course of his employment when he was carousing around on Sunday afternoon and gave the cherry bombs to the children, the only basis for liability would be on the theory of negligent entrustment."). 
In contrast, a negligent entrustment theory of recovery involves no issue of agency or einployment and thus avoids the "scope of employment" and "work-connected" tests. ${ }^{53}$ To incur negligent entrustment liability, an employer need only "entrust" a product to an mexperienced or incoinpetent employee who later injures a fellow worker or an innocent third party..$^{54}$ Neghigent entrustment tlus provides a powerful means of recovery froin a solvent, insured employer for the acts of a poorly insured employee, irrespective of where or when the accident occurred. ${ }^{55}$ Moreover, recent applications of the theory suggest that the full potential of negligent entrustinent has yet to be realized. ${ }^{56}$

Negligent entrustment theory has proven especially useful to injured workers who seek to avoid the strictures of workers' coinpensation statutes. ${ }^{57}$ The statutes' guarantee of coinpensation for job-related injuries

53. See, e.g., Pritchett v. Kimberly Cove, Inc., 568 F.2d 570, 578 \& n.14 (8th Cir. 1977) (employer held liable for negligently entrusting boat to underage employee despite fact that empioyee acted outside scope of employment), cert. denied, 436 U.S. 922 (1978); Collins, 453 F.2d at 513-14 (employer heid liable to injured child for entrusting employee with cherry bombs that employee subsequently gave to children, despite fact that accident and entrustment occurred outside scope of employement); see also Breeding v. Massey, 378 F.2d 171, $177-78$ (8th Cir. 1967) (respondeat superior and negligent entrustment not mutually exclusive; recovery possible under both theories).

54. See supra notes 31-44 and accompanying text (discussing negligent entrustment generally and as applied to sales and leases).

55. See, e.g., Denby v. Davis, 212 Va. 236, 188 S.E.2d 226 (1972) (suit against employer of 20 year-old with congenital eye defect who killed child while on unauthorized driving trip). Plaintiffs have brought suits under similar theories against employers who neghigently serve alcohol to empioyees at company social functions. See, e.g., Chastain v. Litton Sys., 694 F.2d 957, 959, 962 (4th Cir. 1982) (Litton employee drove through red light after company Christmas party, killing plaintiff's decedent; remanded for trial to determine whether Litton negligentiy allowed alcohol to be served to intoxicated employee), cert. denied, 462 U.S. 1106 (1983); Brockett v. Kitchen Boyd Motor Co., 264 Cal. App. 2d 69, 70 Cal. Rptr. 136, 137 (1968), rev'd on other grounds, 24 Cal. App. 3d 87, 88-89, 100 Cal. Rptr. 752, 754-56 (1972) (employee of defendant struck plaintiffs' automobile after underage employee became intoxicated at Christmas party; remanded for trial because serving alcohol to minor is negligence per se); Dickinson v. Edwards, 105 Wash. 2d 457, 459-60, 716 P.2d 814, 818-19 (1986) (employee of defendant, driving after becoming intoxicated at company banquet, struck plaintiff; verdict for plaintiff affirmed because employer's agent was in position and had duty to stop serving intoxicated employee).

56. See, e.g., Buchanan v. Merger Enters., 463 So. 2d 121, 123-28 (Ala. 1984) (negligent entrustment theory used by court against liquor vendor after repeal of dram shop statute and before enactment of tougher version); Fowler v. Park Corp., 673 S.W.2d 749, 753-54, 757-58 (Mo. 1984) (plaintiff recovered largest personal injury verdict in state history, using negligent entrustment theory); Williams v. Steves Indus., 699 S.W.2d 570, 572 (Tex. 1985) (punitive damages may be awarded for grossly negligent entrustment); see also Woods, supra note 11, at 304 (noting weakening of doctrine that negligent entrustment is unavailable when respondeat superior is admitted by empioyer).

57. Statutory compensation for injured workers first appeared in the United States around 1902, when Maryland established an accident fund for employees in certain perilous occupations. See 1902 Md. Laws ch. 139. But see W. Prosser \& W. KeEToN, supra note 45, $\S 80$ (describing New York's 1910 law as first workers' compensation statute). All but eight states had adopted some form of statutory relief by 1920 . Hawaii, in 1963, was the last of the 50 states to enact a workers' compensation law. 1 A. LARSON, supra note $51, \S \S 5.20,5.30$. 
has been regarded as a victory over common law defenses such as contributory negligence and assumption of risk. ${ }^{58}$ Today, however, tort recovery has become easier to obtain, ${ }^{59}$ and many workers might well regret the loss of their common law rights against employers. ${ }^{60}$ More and more often, resourceful workers sue the sellers or lessors of the equipment involved in industrial accidents in the hope of supplementing their workers' compensation benefits. ${ }^{61}$

Workers' compensation benefits are often madequate because they are designed to compensate only those injuries that affect earning power; nonvocational injuries such as pain and suffering and loss of consortium are ignored. ${ }^{62}$ Failure to adjust benefits for inflation and admimistrative delay and disagreement over the degree of a worker's impairment also compound the problem of inadequate recovery in some states. ${ }^{63}$ These problems have led to a perception that benefits under the compensation acts are "not much higher than is necessary to keep the worker froin destitution." 64

58. See W. Prosser \& W. KeEton, supra note $45, \S 80$, at $572-73$ (workers' compensation laws nullified common law defenses that had impeded workers' recovery).

59. The development of the theories of comparative negligence and last clear chance has eroded the formidable defense of contributory negligence, see W. PROSSER \& W. KEETON, supra note 45, $\S \S 66-67$, which often completely barred workers from recovery, see 1 A. LARSON, supra note 51 , $\S 4.30$.

60. Cf. Problems with Worker's Comp. Chicago Tribune, June 19, 1985, $\S 1$, at 18, col. 3 (Collecting workers' compensation from a recalcitrant employer can be a long, expensive process, taking about 12 months for arbitrator decisions and as long as 36 months if appealed; as an injured worker complains, there is nothing guaranteed about workers' compensation's "guaranteed" payments.).

61. Note, Exceptions to the Exclusive Remedy Requirements of Workers' Compensation Statutes, 96 HARV. L. REV. 1641, 1641 (1983)..

62. 1 A. LARson, supra note 51, § 2.40; see also White v. Chrysler Corp., 421 Mich. 192, 19697, 364 N.W.2d 619, 621 (1984) (in action by two workers for injuries to their hands caused by a power press, court noted that "[u]nless there is ... a third person under a legal liability to the injured worker, he has no source of recovery for loss of the non-vocational use of the hand").

63. See Note, supra note 61, at $1643-44$.

64. 1 A. LARSON, supra note $51, \S 2.50$. Most compensation acts award the worker a percentage of his average weekly wage; the type of disability suffered determines the percentage. The award is subject to a maximum total disbursement limit over a specified number of weeks. Id.; see also White, 421 Mich. at 206, 364 N.W.2d at 625 ("The absence of tort liability or other reparations for loss not covered by worker's compensation benefits ... results in the undercompensation of many seriously injured workers."); Johnson \& Heler, Compensation for Death from Asbestos, 37 INDus. \& LAB. REL. REv. 529, 532 tbl. 1 (1984) (study showed that widows of deceased workers recouped average of $36.2 \%$ of lost wages under workers' compensation); Note, supra note 61, at 1645 ("Workers whose injuries are compensable exclusively under workers' compensation can ... be seriously disadvantaged relative to those with access to tort remedies."); Self-Interest Dominates Worker's Compensation Debate, L.A. Times, Aug. 13, 1986, § IV, at 1, col. 2 (state legislature debates whether to raise maximum benefits for workers with short-term disabilities from "ridiculously low" \$224 per week to $\$ 800$ per week).

Congress has noted the problem of undercompensation for workers. In 1979, legislation was proposed in response to a perception that many existing state statutes did not provide "adequate, prompt and equitable" systems of compensation for workers injured in the course of their employ- 
To illustrate a typical situation in which an injured worker might bring a neghigent commercial transaction suit against a merchant, consider the following example:

Worker $W$ is employed as a laborer at a construction site by employer $E$. $E$ recently purchased a construction crane from business $B$. $B$ had recommended the particular model that $E$ purchased because $E$ had stated her need for equipment with simple operating procedures. $E$, in fact, had mentioned to $B$ that her crews were inexperienced. Shortly after the sale, $W$ is permanently paralyzed in a crane accident. The state industrial commission awards $W$ statutory workers' coinpensation benefits ainounting to $66.66 \%$ of $W$ 's average weekly wage for 450 weeks. Both $W$ and his attorney consider this rehef minimal in comparison to today's million dollar tort recoveries. The state workers' compensation act, however, bars $W$ and his dependents from suing $E$. How can $W$ 's attorney find inore compensation for his chent's injuries? Is there a legal basis for recovery against $B$ based on $B$ 's awareness that $E$ 's crane crew was inexperienced? ${ }^{65}$

Although the purpose of all workers' compensation acts is to give injured employees an exclusive remedy ${ }^{66}$ against their einployers without the need for litigation on the issue of fault, ${ }^{67}$ the exclusive remedy rule

ment. H.R. 5482, 96th Cong., 2d Sess. $\$ 2(a)(6)(1979)$, reprinted in National Workers' Compensation Standards Act of 1979: Hearings on H.R. 5482 Before the Subcomm. on Labor Standards of the House Comm. on Education and Labor, 96th Cong., 2d Sess. 3, 4 (1980).

65. This example derives from Barsness v. General Diesel \& Equip. Co., 383 N.W.2d 840 (N.D. 1986), and North Dakota's workers' compensation statutes, N.D. CENT. CODE $\S \S 65-05-09,65-05-$ 12 (1985 \& Supp. 1987).

66. In an action by an employee or his dependents, the exclusivity rule of workers' compensation remedies generally insulates the employer from common law and statutory tort liability, as well as liability that may arise in contract or admiralty. See Silkwood v. Kerr-McGee Corp., 769 F.2d 1451, 1467 (10th Cir. 1985) (plaintiff's claim for decedent's personal injuries from plutonium contamination barred under exclusivity rule of Oklahoma Workers' Compensation Act, but punitive damages allowed), cert. denied, 476 U.S. 1104 (1986); U.S. Borax \& Chem. Corp. v. Superior Court, 167 Cal. App. 3d 406, 410, 213 Cal. Rptr. 155, 157 (1985) (wrongful death action against employer arising out of industrial accident barred by exclusivity rule); Henderson v. State, 110 Idaho 308, 309, 715 P.2d 978, 979 (claim for damages allegedly incurred in scope of employment barred by exclusive remedy provision of Idaho's compensation statutes), cert. denied, 477 U.S. 907 (1986); see also $2 \mathrm{~A}$ A. LARSON, supra note $51, \S \S 65.00,65.11$. One exception to the rule arises if the employer commits an intentional tort against his employee. Id. $\$ \S 68.00,68.11$.

67. Early court challenges to compensation statutes found the principle of liability without fault to be an unconstitutional taking of employers' property without due process of law. See Ives v. South Buffalo Ry. Co., 201 N.Y. 271, 294, 94 N.E. 431, 439 (1911), overruled, Montgomery v. Daniels, 38 N.Y.2d 41, 340 N.E.2d 444, 378 N.Y.S.2d 1 (1979). Professor Larson has noted that the fear of unconstitutionality forced legislatures "to pass over the ideal type of coverage, which would have been both comprehensive and compulsory." 1 A. LARSON, supra note $51, \S 5.20$, at 38 . Under 
does not apply to employee actions against a third party or "ultimate wrongdoer."68 A common law negligent commercial transaction suit may thus avoid statutory restrictions and allow an injured worker to recover damages froin mercliants outside the employment relationship. ${ }^{69}$ A merchant doing business with an employer nnay thus be exposed to greater potential liability than the employer. ${ }^{70}$

\section{B. Dram Shop Liability as a Precedent for the Negligent Commercial Transaction Tort.}

The idea that judges can create a right of action to give relief to undercompensated third parties for injuries resulting froin the sale of a nondefective product is not new. Indeed, judge-nnade liability for merchants who do business witli incoinpetent or inexperienced clients already exists under the doctrine of "drain sliop" liability. ${ }^{71}$

Originally established by statute in the nineteenth century, ${ }^{72}$ dram shop liability is the potential civil liability of liquor vendors to third parties for injuries caused by intoxicated or underage patrons. ${ }^{73}$ Most of the early dram shop statutes were repealed or fell into disuse inmediately

the eventual compromise, employers accepted workers' compensation coverage in exchange for relief from the risk of large tort verdicts. Cf. Bradford Elec. Light v. Clapper, 286 U.S. 145, 159 (1932) (Brandeis, J.) (purpose of workers' compensation laws in most states is to provide "not only for employees a remedy which is both expeditious and independent of proof of fault, but also for enployers a liability which is linited and determinate"); accord Smither \& Co. v. Coles, 242 F.2d 220, 222 (D.C. Cir.), cert. denied, 354 U.S. 914 (1957) (exclusivity of remedy is keystone of worker's compensation law).

68. See, e.g., Burk v. Cities Serv. Oil Co., 266 F.2d 433, 435 (10th Cir. 1959) (Oklahoma's workers' compensation act preserves common law remedies against third-party tortfeasors); Bowman v. Atlanta Baggage \& Cab, 173 F. Supp. 282, 285 (N.D. Fla. 1959) (workers' compensation does not preclude common law action against parties outside employer-employee relationship); Price v. King, 259 Iowa 921, 924, 146 N.W.2d 328, 329 (1966) ("[T] he [compensation] act does not deny an employee the common law right to recover damages caused by the negligence of a third person even though he has received workmen's compensation benefits for the same injury."). See generally 2A A. LARSON, supra note 51, $\S \S 67.21,71.00,71.10$; Birnbaum \& Wrubel, Workers' Compensation and the Employer's Immunity Shield: Recent Exceptions to Exclusivity, 5 J. PROD. LiAB. 119 (1982).

69. See, e.g., Fowler v. Park Corp., 673 S.W.2d 749 (Mo. 1984) (en banc) (injured worker sues railroad engine lessor); Barsness v. General Diesel \& Equip. Co., 383 N.W.2d 840 (N.D. 1986) (injured worker sues construction crane lessor).

70. For example, in Fowler, 673 S.W.2d at 757-58, a worker won a $\$ 6$ million verdict froin a merchant, a sum far in excess of any state's employer-financed workers' coinpensation benefits.

71. Dram shops were nineteenth-century establishments that sold alcoholic beverages by a unit of measure called a "dram." Colman, Krell \& Mosher, Preventing Alcohol-Related Injuries: Dram Shop Liability in a Public Health Perspective, 12 W. ST. U.L. REv. 417, 443 n.l (1985).

72. Wisconsin passed the first dram shop law in 1849. The law required tavern owners to post a bond to pay civil or criminal judgments against them for illegal sales of alcohol. By the mid-1870s, 11 states had passed dram shop acts. Goldberg, One for the Road: Liquor Liability Broadens, A.B.A. J., June 1987, at $84,86$.

73. Comment, supra note 26, at 1015. 
following Prohibition; ${ }^{74}$ further, in jurisdictions where no dram shop statute was in force, courts generally did not impose hability. ${ }^{75}$ Today, however, courts have increasingly rejected this position. ${ }^{76}$

Since about 1970, dram shop liability has reemerged at a dramatic pace, coincident witl society's increased concern for drunk driving and its victims. ${ }^{77}$ Thirty states currently have some kind of dram shop act. ${ }^{78}$

74. See, e.g., Adamian v. Three Sons, Inc., 353 Mass. 498, 500, 233 N.E.2d 18, 19 (1968); Rappaport v. Nichols, 31 N.J. 188, 200-01, 156 A.2d 1, 8 (1959). See generally Colman, Krell \& Mosher, supra note 71 , at 443.

75. See, e.g., Fudge v. City of Kansas City, 239 Kan. 369, 375-76, 720 P.2d 1093, 1100 (1986); see also Ontiveros v. Borak, 136 Ariz. 500, 504, 667 P.2d 200, 204 (1983) (en banc) (stating and rejecting traditional rule of nonliability); Pike v. George, 434 S.W.2d 626, 629 (Ky. 1968) (acknowledging general rule of nonliabihty but declining to apply it in all circumstances). The traditional rule of nonliability stemmed from three principal sources:

(1) the presumption that consumption, and not the sale, of the alcoholic beverage is the proximate cause of injuries sustained; (2) traditional social mores, dating back to Prohibition, which hold the drinker morally and legally liable for his own actions; and (3) the constitutional doctrine that courts should defer questions of hability to the legislature.

Colman, Krell \& Mosher, supra note 71, at 419; see also Williamson v. Old Brogue, Inc., $232 \mathrm{Va}$. $350,353-54,350$ S.E.2d 621, 623-24 (1986) (reaffirming Virginia's traditional common law rule of nonhability).

76. The seminal case rejecting the traditional common law rule of nonliabihty and adopting a new judge-made rule is Rappaport, 31 N.J. at 205-06, $156 \mathrm{~A} .2 \mathrm{~d}$ at 10.

77. See generally Rinden, Judicial Prohibition? Erosion of the Common Law Rule of Non-Liability for Those Who Dispense Alcohol, 34 DRAKE L. REV. 937, 937-40 (1985-1986); $c f$. PRESIDENTIAL COMM'N ON DRUNK DRIVING, FINAL REPORT 1 (1983) (estimating that, over 10-year period, $50 \%$ of all U.S. highway fatalities involved alcohol, resulting in 250,000 American deaths and a $\$ 21$ billion annual economic loss).

This recent expansion of dram shop hability has been a welcome source of additional compensation for injured plaintiffs. Formerly, a plaintiff harmed by an intoxicated tortfeasor could recover only against that tortfeasor, who may or may not have been adequately insured. See, e.g., Olsen v. Copeland, 90 Wis. 2 d 483, 491, 280 N.W.2d 178, 181-82 (1979) ("The problem presented by this issue is not one of adequate remedies for an injured plaintiff. There seems to be little reason to provide the person imjured by an intoxicated driver with a deeper pocket than the person injured by the stupid driver, the careless driver or the drugged driver."), overruled, Sorensen v. Jarvis, 119 Wis. 2d 627, 646-48, 350 N.W.2d 108, $117-19$ (1984); Fugate v. Galvin, 84 Ill. App. 3d 573, 577, 406 N.E.2d 19, 22 (1980) ("The fortuitous circumstance of one driver's inability to pay for damages he has caused should not be a reason to open new arenas of hability in search of perfect compensation scheines."). In today's liquor liability cases, however, plaintiffs may extract many times more in monetary damages from taveru owners than from individual drunk drivers. In Michigan, for example, a tavern's insurance company settled a wrongful death claim for over $\$ 7$ million (not in present value terms). Cansler v. Pine Knob Invest. Co., No. 84-275551-NI (Mich. Cir. Ct. Oakland County, settled Oct. 25, 1985). Similarly, in Ohio, widows of two decedents killed by a drunk tavern patron sued the tavern for $\$ 24$ million. Hargraves v. Brown, No. CV85-09-1043 (Ohio C.P. Ct., Butler County, filed Sept. 25, 1985). Not surprisingly, the estimated annual growth rate for alcohol-server liability litigation is now approaching $300 \%$. Goldberg, supra note 72 , at 84 .

78. Ala. CoDE $\$ \S 6-5-70,-71$ (1975); Alaska Stat. $\$ 04.21 .020$ (1986); ARIz. Rev, Stat. ANN. §§ 4-311, -312 (Supp. 1986-1987); CAI. Bus. \& Prof. CoDE § 25,602.1 (West Supp. 1988); Colo. Rev. STAT. $\S 12-46-112.5$ (Supp. 1987); ConN. GEN. STAT. ANN. \$ 30-102 (WVest Supp. 1988); Fla. STAT. ANN. § 768.125 (West Supp. 1988); GA. CoDE ANN. § 3-3-22 (1982); IDAHo CODE § 23-808 (Supp. 1988); ILl. ANN. STAT. ch. 43, § 135 (Smith-Hurd 1986 \& Supp. 1988); IND. Code ANN. § 7.1-5-10-15.5 (Burns Supp. 1988); IowA Code ANN. § 123.92 (West 1987); ME. 
The courts of ten other states and the District of Columbia, inspired by the national trend, have created dram shop liability by judicial decree. ${ }^{79}$ Only ten states fail to give injured plaintiffs a statutory or judge-made cause of action against those who sell alcohol to underage or intoxicated tortfeasors. ${ }^{80}$

Judicial development of dram shop liability in the absence of an applicable statute typically involves a process in which a court identifies a social problem, notes the legislature's failure to act, and then uses the common law to fashion a solution. For example, the dramatic shift in legislative and judicial opinion on dram shop liability stems from the spread of alcohol-related accidents on American roads. ${ }^{81}$ Courts have

Rev. STAT. ANN. tit. 28-A, §\$ 2501-19 (Supp. 1987); Mich. CoMp. LAWS ANN. §436.22 (West Supp. 1988); MinN. Stat. ANN. §340A.801 (West Supp. 1988); Mo. AnN. STAT. § 537.053 (Vernon 1988); MoNT. CODE ANN. § 27-1-710 (1987); N.H. Rev. STAT. ANN. §§ 507-F:1 to -F:8 (Supp. 1987); N.M. STAT. ANN. § 41-11-1 (Supp. 1987); N.Y. GeN. Oblig. LAw § 11-101 (McKinney 1978 \& Supp. 1988); N.C. GEN. STAT. \$§ 18B-120 to -129 (1983); N.D. CENT. CODE § 5-0106.1 (1987); OHIo Rev. CODE ANN. § 4399.01-.09 (Anderson 1982 \& Supp. 1987); OR. REv. STAT. ANN. $\S \$ 30.950-.960$ (Butterworth 1988 Repl.); PA. Cons. STAT. ANN. $\S 47-4-497$ (Purdon 1969 \& Supp. 1988); R.I. GEN. LAwS $\S \S 3-14-1$ to -15 (Supp. 1986); UTAH CODE ANN. $§ 32 A-14-1$ to -2 (1986); VT. STAT. ANN. tit. 7, § 501 (1972 \& Supp. 1987); Wis. STAT. ANN. § 125.035 (West Supp. 1987); WYO. STAT. §§ 12-5-502, 12-8-301 (1986).

Maine and Rhode Island have recently passed laws patterned after the Model Dram Shop Act, sometimes called the Liquor Liability Act. Authored by the Prevention Research Group under a federal grant, the Model Act appears in Colman, Krell \& Mosher, supra note 71, at 442.

Many of the the 30 states that now have statutory dram shop liability recognized a common law cause of action before they adopted dram shop statutes. See, e.g., Ontiveros v. Borak, 136 Ariz. 500, 513, 667 P.2d 200, 213 (1983); Alegria v. Payonk, 101 Idaho 617, 621, 619 P.2d 135, 139 (1980); Lopez v. Maez, 98 N.M. 625, 632, 651 P.2d 1269, 1276 (1982); Sorensen v. Jarvis, 119 Wis. 2d 627, 646, 350 N.W.2d 108, 115-17 (1984).

79.' See Rong You Zhou v. Jennifer Mall Restaurant, Inc., 534 A.2d 1268 (D.C. 1987); Ono v. Applegate, 62 Haw. 131, 138, 612 P.2d 533, 537-38 (1980); Pike, 434 S.W.2d at 629; Chausse v. Southland Corp., 400 So. 2d 1199, 1203 (La. Ct. App.), cert. and review denied, 404 So. $2 \mathrm{~d} 278$ (La. 1981); Adamian v. Three Sons, Inc., 353 Mass. 498, 501, 233 N.E.2d 18, 20 (1968); Munford, Inc. v. Peterson, 368 So. 2d 213, 217 (Miss. 1979); Rappaport, 31 N.J. at 202-03, 156 A.2d at 9-10; Brigance v. Velvet Dove Restaurant, Inc., 725 P.2d 300, 304 (Okla. 1986); Mitchell v. Ketner, 54 Tenn. App. 656, 665, 393 S.W.2d 755, 759 (1964) (dicta); Poole v. El Chico Corp., 713 S.W.2d 955, 958 (Tex. Ct. App. 1986), aff'd, 732 S.w.2d 306 (Tex. 1987); Young v. Caravan Corp., 99 Wash. 2d 655, 658-60, 663 P.2d 834, 837-38, amended, 672 P.2d 1267 (1983).

80. Delaware, Kansas, Maryland, and Virginia continue to follow the common law rule of nonliability for alcohol sellers. See Wright v. Moffitt, 437 A.2d 554 (Del. 1981) (no dram shop liability); Fudge v. City of Kansas City, 239 Kan. 369, 720 P.2d 1093 (1986) (no dram shop liability recognized); Felder v. Butler, 292 Md. 174, 438 A.2d 494 (1981) (no civil liability under statute proscribing sales to intoxicated persons); Williamson v. The Old Brogue, Inc., 232 Va. 350, 350 S.E.2d 621 (1986). South Dakota has provided statutory civil immunity. See S.D. Codified LAwS ANN. $\S \S 35-4-78,35-11-1$ (1986 Rev. \& Supp. 1988). To date, there are no cases or statutes addressing dram shop liability in Arkansas, Nebraska, Nevada, South Carolina or West Virginia.

81. See Ontiveros, 136 Ariz. at 507, 667 P.2d at 207 (common law rule of nonliability for tavern owners anachronistic in view of "frightful toll" of alcohol-related traffic fatalities and injuries); Presidential COMm'N ON DrUNK DRIVING, supra note 77, at 11; cf. Kelly v. Gwinnell, 96 N.J. 538, 545-46 \& n.3, 476 A.2d 1219, 1222 \& n.3 (1984) (noting huge cost to state of alcohol-related 
noted the problem of inadequate compensation for victims of such accidents, and where legislatures have failed to confront this problem, some courts have been inspired to take judicial action. ${ }^{82}$

In support of its action to abrogate the rule of nonliability, such a court could argue that: (1) dram shop hability is analogous to hability for negligent entrustment of firearms or automobiles to minors, intoxicated persons, and incompetents; 83 (2) the national trend toward dram shop liability should give suppliers of alcohol fair notice to carry adequate liability insurance; 84 and (3) there is a pressing need to compensate the innocent victims of alcohol-related accidents. ${ }^{85}$ Based on these arguments, the court could claim that the rule of nonliability is "an anachronism, unsuitable to our present society, and . . . repugnant to modern tort

personal injuries and property damage, estimated at $\$ 1,149,516,000$ for $1978-1982$, as a factor in favor of imposiug liability on hosts for injuries caused by intoxicated guests).

When inost people walked and few had horses or carriages, or even in the days when the horse and buggy was a customary mode of travel, it may have been that the common law rule of law of non-liability arising from the sale of liquor to an intoxicated persou was satisfactory. But the situation then and the problem in today's society of the imbiber going upon the public highways and operating a machine that requires quick respouse of mind and inuscle and capable of produciug mass death and destructiou are vastly differeut.

Meade v. Freeman, 93 Idaho 389, 400, 462 P.2d 54, 65 (1969) (Prather, J., concurring speeially in result and dissenting iu part), overruled, Alegria v. Payonk, 101 Idaho 617, 621, 619 P.2d 135, 139 (1980). In his Meade dissent, Judge Prather argued in favor of a common law cause of action. See id. at 395-403, 462 P.2d at 60-68. The Idaho Supreme Court overruled Meade "to the extent that it infers that under common-law rule and present statutes the vending of intoxicants can never be tlie proximate cause of damage to third parties resulting from the tortious or unlawful acts of the consumer." Alegria, 101 Idaho at 621, 619 P.2d at 139 (emphasis in original).

82. E.g., Brigance v. Velvet Dove Restaurant, Iuc., 725 P.2d 300, 303 (Okla. 1986) ("Because the Legislature has failed to act to impose civil liability, for reasous unknown, does not unequivocally demonstrate legislative inteut."); Ontiveros, 136 Ariz. at 512, 667 P.2d at 212 ("The legislature inay well believe that when a judge-made common law rule lias become obsolesceut, anachronistic and unjust, the responsibility for change is ours, not theirs.").

83. See Branuigan v. Raybuck, 136 Ariz. 513, 516, 667 P.2d 213, 216 (1983); Ontiveros, 136 Ariz. at 509, 667 P.2d at 209 (citing seminal case involving uegligent sale of automobile, Johnson v. Casetta, 197 Cal. App. 2d 272, 17 Cal. Rptr. 81 (1961)); Jardine v. Upper Darby Lodge No. 1973, Inc., $413 \mathrm{~Pa} .626,631,198$ A.2d 550, 553 (1964) (serving alcohol to intoxicated patron with car akin to entrusting demeuted iudividual with gun); $c f . K e l l y, 96$ N.J. at 549, 476 A.2d at 1224-25 (social host's liability for serving intoxicated guest analogous to car owner's liability for lending car to intoxicated persou).

84. See, e.g., Sorensen v. Jarvis, 119 Wis. $2 d$ 627, 647, 350 N.W.2d 108, 118 (1984). Presumably, vendors would pass the costs of additional insurance on to their customers.

85. See Rappaport v. Nichols, 31 N.J. 188, 205, 156 A.2d 1, 10 (1959) ("[R]ecognition of the plaintiff's claim will afford a fairer measure of justice to innocent third parties whose injuries are brought about by the unlawful and uegligeut sale of alcoholic beverages to minors and intoxicated persons ...."); Presidential Comm'N ON DRUNK DRIVING, supra note 77, at 11 (recommending dram shop liability as way to reduce number of accidents); see also ME. REv. STAT. ANN. tit. 28-A, $\S 2502$ (2)(A) (Supp. 1987) (secondary purpose of Maine's Liquor Liability Act is to "[e]stablish a legal basis for obtaining compensation for those suffering daunages as a result of intoxication-related iucidents in aecordance with this Act"). 
theories." 86 The court could then decide that it can no longer "escape responsibility behind the hoary doctrine of stare decisis," 87 and it could rationalize that its abrogation of the rule of nonliability is not judicial legislation by asserting:

The common law, which is judge-made and judge-apphed, can and will be changed when changed conditions and circumstances establish that it is unjust or has become bad public policy. In reevaluating previous decisions in light of present facts and circumstances, we do not depart from the proper role of the judiciary. ${ }^{88}$

Several state legislatures have reacted with alarm to such assertions and to the courts' increased willingness to engineer solutions to social problems. In the case of dram shop hability, for example, some legislatures have overturned court decisions or clarified the himits of liability under existing dram shop acts. ${ }^{89}$ These lawmakers have sought to restrain the judiciary from expanding common law hability too far, or to interdict the new judge-made rules before they become too entrenched. ${ }^{90}$ The growth of the judge-made negligent commercial transaction doctrine, however, has yet to draw a rebuke from state legislatures.

\section{Negligent Commercial Transaction Caselaw}

Today, some state courts no longer recognize any real distinction between merchants who violate statutory duties by selling alcohol or weapons to certain classes of individuals and inerchants who sell or lease equipment to inexperienced or incompetent users without violating any

86. Lewis v. Wolf, 122 Ariz. 567, 570, 596 P.2d 705, 708 (Ct. App. 1979), overruled, Ontiveros, 136 Ariz. at 507-08, 667 P.2d at 207.08.

87. Meade v. Freeman, 93 Idaho 389, 401, 462 P.2d 54, 66 (1969) (Prather, J., concurring specially in result, dissenting in part), overruled, Alegria v. Payonk, 101 Idaho 617, 621, 619 P.2d 135,139 (1980).

88. Ontiveros, 136 Ariz. at 504, 667 P.2d at 204.

89. See, e.g., CAL. Bus. \& Prof. CoDE $\S \S 25,602$ (c), 25,602.1 (West 1985 \& Supp. 1988) (abrogating Coulter v. Superior Court, 21 Cal. 3d 144, 577 P.2d 669, 145 Cal. Rptr. 534 (1978); Bernhard v. Harrah's Club, 16 Cal. 3d 313, 546 P.2d 719, 128 Cal. Rptr. 215, cert denied, 429 U.S. 859 (1976); Vesely v. Sager, 5 Cal. 3d 153, 486 P.2d 151, 95 Cal. Rptr. 623 (1971), and providing civil immunity to commercial vendors, except in the case of sales to obviously intoxicated minors); Mo. ANN. STAT. § 537.053 (Vernon 1988) (abrogating Carver v. Schafer, 647 S.W.2d 570 (Mo. Ct. App. 1983); Nesbitt v. Westport Square, Ltd., 624 S.W.2d 519 (Mo. Ct. App. 1981); Sampson v. W.F. Enter., Inc., 611 S.W.2d 333 (Mo. Ct. App. 1980), and providing civil immurity to commercial vendors, except in cases of sales to minors or obviously intoxicated persons); S.D. Codified Laws ANN. $\S \S 35-478,-11-1$ (1986 Rev. \& Supp. 1988) (abrogating Walz v. City of Hudson, 327 N.W.2d 120 (S.D. 1982), and providing complete civil immunity to commercial vendors).

90. Some courts that have held hosts hable for their drunken guests' torts have also faced legislative abrogation of their decisions. See, e.g., Coulter, $21 \mathrm{Cal} .3 \mathrm{~d}$ at 152, 577 P.2d at 672, 145 Cal. Rptr. at 538, abrogated by CAL. Bus. \& PROF. CODE § 25,602(c) (West 1985); Wiener v. Gamma Phi Chapter of Alpha Tau Onega Fraternity, 258 Or. 632, 643, 485 P.2d 18, 23 (1971), limited by 1979 Or. Laws ch. 801, § 2, repealed by 1987 Or. Laws ch. 774, § 14. 
statutory duty. Inspired by the revision of section 390 in the Restatement (Second) of Torts, the recent trends in common law dram shop liability, and the notion that the judiciary can alleviate social probleins through expanded tort liability, courts in Alaska, ${ }^{91}$ California, ${ }^{92}$ Missouri, ${ }^{93}$ and North Dakota ${ }^{94}$ liave recognized a new common law cause of action against merchants. Under this new rule, a sale or lease of goods to a customer who the mercliant knows or should know is inexperienced or incoinpetent establishes a prima facie case of negligence against the mercliant in favor of third parties injured through the customer's use of the product.95 The future of this cause of action is unclear. Although most of the current caselaw involves automobile sales to incoinpetent drivers, ${ }^{96}$ the doctrine has been successfully applied in other contexts as well. ${ }^{97}$ So far, only Florida lias exphicitly rejected the trend, noting the adverse commercial impact of the new action. ${ }^{98}$

\section{A. Commercial Leases.}

Where leases are concerned, courts have traditionally limited the doctrine of negligent commercial transactions to cases involving car rentals to unlicensed or intoxicated drivers. ${ }^{99}$ Two courts, however, have recently found this approach too restrictive and have extended the doctrine to commercial leases involving products other than autos.

First, in Barsness v. General Diesel \& Equipment Co., 100 the Supreine Court of Nortlı Dakota unanimously recognized a right of action against a construction crane lessor based on evidence that the lessee, who was the plaintiff's einployer, nay have had limited experience in

91. See Flieger v. Barcia, 674 P.2d 299, 301 (Alaska 1983) (owner of vehicle may become liable for negligent entrustment by selling vehicle to another).

92. See O'Toole v. Carlsbad Shell Serv. Station, 202 Cal. App. 3d 151, 247 Cal. Rptr. 663, 66971 (ordered not published in California Appellate Reports; opinion appears in California Reporter advance sheets), review denied, [no docket number] (Cal. Aug. 18, 1988) (LEXIS, 1988 Cal. LEXIS 220); Johnson v. Casetta, 197 Cal. App. 2d 272, 274-75, 17 Cal. Rptr. 81, 82-83 (1961).

93. See Fowler v. Park Corp., 673 S.W.2d 749, 753-54 (Mo. 1984) (en banc).

94. See Barsness v. General Diesel \& Equip. Co., 383 N.W.2d 840, 845-46 (N.D. 1986).

95. See supra note 7 and accompanying text.

96. See infra notes 108-25 and accompanying text.

97. See supra notes 15-19 and accompanying text.

98. See Vic Potamkin Chevrolet, Inc. v. Horne, 505 So. 2d 560, 562, 563 (Fla. Dist. Ct. App. 1987) (en banc), aff'd, No. 70,499, slip op. (Fla. Sept. 1, 1988) (Westlaw, 1988 WL 93694); see also Jackson v. Turnipseed, 512 So. 2d 213, 213 (Fla. Dist. Ct. App. 1987) (per curiam). A few states have refused to extend liability to sellers of automobiles, reasoning that such sales are simply outside the proper scope of negligent entrustment. See, e.g., Tosh v. Scott, 129 IIl. App. 3d 322, 472 N.E.2d 591 (1984); Kirk v. Miller, 7 Kan. App. 2d 504, 644 P.2d 486 (1982).

99. See, e.g., Owens v. Carmichael's U-Drive Autos, Inc., 116 Cal. App. 348, 350-51, 2 P.2d 580,581 (1931) (action against rental agent for leasing car to unlicensed driver).

100. 383 N.W.2d 840 (N.D. 1986). 
operating such cranes. The plaintiff, a construction worker, was injured after a manbasket in which he was riding tumbled thirty-five feet to the ground. Both parties stipulated that the manbasket had been negligently rigged. The injured worker sought recovery based on negligent entrustment, to which the court replied, "we see no reason why the doctrine should not apply to ... chattels [other than autoinobiles] which, if placed in the hands of an incoinpetent or inexperienced person, present a likelihood of unreasonable risk of harm to third persons." 101 Despite the fact that the plaintiff's employer had previously leased a crane froin the lessor without incident, the court held, on motion for summary judgment, that there existed a genuine issue of fact concerning the einployer's experience with cranes and that the action should proceed to trial. ${ }^{102}$

Second, in Fowler v. Park Corp., ${ }^{103}$ a divided Missouri Supreme Court relied on section 390 of the Restatement (Second) of Torts in affirning a six-1nillion-dollar judgment in a negligence action. The case involved a corporate defendant that had leased part of an industrial park to the employer of the plaintiff, a mineteen-year-old sandblaster. The park contained a railroad engine, and during night shifts, the plaintiff's fellow employees custonnarily used the engine to conduct switching operations for the entire yard. These employees lacked formal instruction or training in switching, in the operation of engines, and in general safety procedures; ${ }^{104}$ the einployees' inexperience with the engine led to an accident that cost the plaintiff both his legs. In upholding the plaintiff's action against the lessor-defendant, the Missouri Supreme Court declared that the lessor "had a duty to make sure that [the lessee-employer] allowed only competent persons to operate [the engine]." 105 Noting the young worker's pitiful physical condition, the court affirned the largest personal injury verdict ever awarded in Missouri. ${ }^{106}$

\section{B. Common Law Negligent Sales.}

For years, California stood alone in recognizing a counmon law action for the negligent sale of a non-alcoliolic, nonletlial product. ${ }^{107}$ The seminal 1961 California case, Johnson v. Casetta, ${ }^{108}$ involved the negligent sale of an automobile to an incompetent driver. Later cases, such as

101. Id. at 842 .

102. Id. at 845 .

103. 673 S.W.2d 749 (Mo. 1984) (en banc).

104. Id. at 751 .

105. Id. at 753 .

106. Id. at 757-58.

107. Cf. supra notes $26-30$ and accompanying text (noting traditional focus of negligent commercial transaction doctrine on sales of alcohol and weapons in violation of statutes).

108. 197 Cal. App. 2d 272, 17 Cal. Rptr. 81 (1961). 
Roland v. Golden Bay Chevrolet ${ }^{109}$ and Dillon v. Suburban Motors, Inc., ${ }^{110}$ reaffirmed California's commitment to providing a remedy for third parties imjured by neghigently sold automobiles. ${ }^{111}$ These cases created the rule that a plamtiff can establish a prima facie case of neghigence by presenting evidence that an automobile seller knew or should have known that the buyer who mjured the plaintiff was an incompetent driver.

In Johnson, the plaintiff brought an action based on section 390 of the first Restatement of Torts against a used-car dealer for the wrongful death of their son and for other personal injuries. ${ }^{112}$ In that case, the car dealership had sold an automobile to a non-Enghish-speaking native of Mexico. Soine weeks after the sale, the car buyer swerved across a center line and into the plaintiff's oncoming vehicle. The plaintiffs asserted that the buyer had virtually no driving experience and that the seller knew or should have known that the buyer was an incoinpetent driver. ${ }^{113}$ The Johnson court, relying principally on section 390 of the first Restatement of Torts and on negligent entrustment cases involving loaned autornobiles, held that the plaintiffs could have established a cause of action against the seller of the automobile had they offered sufficient proof of their assertions. ${ }^{114}$

The Roland v. Golden Bay Chevrolet court cited Johnson in holding that a third party established a prima facie case of neghigence agamst a car seller for injuries inflicted by a buyer's vehicle. ${ }^{115}$ The court admitted that car sellers have no duty to investigate a buyer's license, ${ }^{116}$ but held that if circuunstances that alert a seller to a buyer's unlicensed status (and therefore his incompetence) fortuitously arise and the seller nevertheless

109. 161 Cal. App. 3d 102, 207 Cal. Rptr. 413 (1984) (opinion omitted from California Appellate Reports), dismissed as moot, 704 P.2d 175, 217 Cal. Rptr. 415 (Cal. 1985) (en banc).

110. 166 Cal. App. 3d 233, 212 Cal. Rptr. 360 (opinion omitted from California Appellate Reports at California Supreme Court's direction), dismissed as moot, 705 P.2d 1260, 218 Cal. Rptr. 584 (Cal. 1985) (en banc).

111. The California courts have been willing to recognize common law liability for negligent sales under Johnson and section 390 of the Restatement (Second) only for injuries to third persons. They have not been willing to grant a right of action to the estate of an unlicensed, injured buyer who, through her own negligence, kills herself. See Perez v. G \& W Chevrolet, Inc., 274 Cal. App. 2d 766, 79 Cal. Rptr. 287 (1969). Other states have taken the position that the sale of automobiles is simply beyond the scope of negligent entrustment doctrine. See supra note 98.

112. $197 \mathrm{Cal}$. App. 2d at 272, 17 Cal. Rptr. at 81 .

113. Id. at $272-74,17 \mathrm{Cal}$. Rptr. at 82 .

114. See id. at $276,17 \mathrm{Cal}$. Rptr. at 83 ; cf. supra note 45 (discussing negligent entrustment cases that involve entrustment-as opposed to sale-of automobiles and other dangerous instrumentalities by an owner to an incompetent).

115. Roland v. Golden Bay Chevrolet, 161 Cal. App. 3d 102, 207 Cal. Rptr. 413, 417-19 (1984) (opinion omitted from California Appellate Reports), dismissed as moot, 704 P.2d 175, 217 Cal. Rptr. 415 (Cal. 1985) (en banc).

116. 207 Cal. Rptr. at $416-17$. 
completes the sale, then a third party mjured as a result of the buyer's incompetence as a driver has a cause of action. ${ }^{117}$ The court noted that Golden Bay's customary business practice mcluded checking licenses and that the dealership claimed to have seen the buyer's license. ${ }^{118}$ As it turned out, the buyer had nothing but a passport. ${ }^{119}$

Dillon v. Suburban Motors, Inc. ${ }^{120}$ expanded Roland by effectively imposing a duty on automobile sellers to demand that patrons produce a driver's license as evidence of their coinpetence to drive ${ }^{121}$ and, if possible, to "unwind" financing deals and "retake possession" of vehicles should evidence of a buyer's incoinpetence later arise. ${ }^{122}$ In Dillon, a mother and son, both of whom held valid Missouri licenses, jointly purcliased an autoinobile in California. The dealer knew that the minor son would operate the car about twenty-five percent of the time. The son, while speeding, caused an accident that killed three people and injured nine others. The injured plaintiffs sought to prove that the minor had failed California's written driver's examination and that the dealer had knowledge of this failure. The court noted tliat Suburban liad violated its own financing procedures by dehivering possession before the purchasers had obtained California hicenses. It also noted that California law requires minors from other states who intend to drive to obtain California licenses within ten days after they establislı state residency. At no time did Suburban attempt to ascertain whether the buyers were legal residents of California. ${ }^{123}$ The court determined that Suburban should have discovered the minor's incompetence and held that Suburban's conduct gave rise to a cause of action. ${ }^{124}$

The Dillon court seemed unimpressed by the fact that the financing agreement for the car in question apparently nained only the inother, or

117. Id. at $418-19$.

118. Id. at 418 .

119. Id. at $415-16$.

120. 166 Cal. App. 3d 233, 212 Cal. Rptr. 360 (opinion omitted from California Appellate Reports at California Supreme Court's direction), dismissed as moot, 705 P.2d 1260, 218 Cal. Rptr. 584 (Cal. 1985) (en banc).

121. 212 Cal. Rptr. at 369. Relying on Hartford Accident \& Indem. Co. v. Abdullah, 94 Cal. App. 3d 81, 156 Cal. Rptr. 254 (1979), the Dillon court stated that car dealers who sell large numbers of cars must take "adequate precautions" to protect the public from harm, such as "requiring the production of evidence from a prospective user of competency to drive." 212 Cal. Rptr. at 369 (quoting Abdullah, $94 \mathrm{Cal}$. App. 3d at 94, $156 \mathrm{Cal}$. Rptr. at 262). The Abdullah case, however, is distinguishable from Dillon. In Abdullah, a used-car dealer entrusted an automobile to an individual for a test drive without first checking to sec that the driver was licensed. The driver failed to return the car and, two days later, while driving the car, caused a collision that seriously injured third parties. The test driver lacked a valid license.

122. Dillon, 212 Cal. Rptr. at 367.

123. Id. at $363-64,366$.

124. Id. at 367. 
by evidence indicating that the mother intended to use the vehicle seventy-five percent of the time. ${ }^{125}$ Dillon seems to support the proposition that any knowledge on the part of a dealer that an unqualified driver intends to take part in the purchase and use of a vehicle creates a duty to avoid the transaction altogether.

California's tort of negligent sales has targeted other goods as well. ${ }^{126}$ Until very recently, suits outside the auto sales context have failed in California not because one can negligently sell only automobiles, but because no plamtiff mjured by a different product has been able to prove the elements necessary to establish liability. ${ }^{127}$ For example, in Henderson Brothers Stores, Inc. v. Smiley, a plaintiff brought an action against a merchant after a tar kettle exploded durnig a roofing job and damaged a nearby warehouse. ${ }^{128}$ The court held that the action based on section 390 failed because the buyer was a licensed, experienced roofer and a prior owner of tar kettles. ${ }^{129}$

In O'Toole v. Carlsbad Shell Service Station, a California appellate court recently recognized a common law action against a seller for neghgently selling (nondefective) gasoline to an incoinpetent, intoxicated driver. ${ }^{130}$ O'Toole is the first California case in whicl a plaintiff successfully stated a common law cause of action for the negligent sale of a product other than an autoinobile. 131

The facts of $O$ 'Toole evoke sympathy for the plaintiffs, children of a victim struck and killed by an intoxicated purchaser, and anger toward the merchant. Late one night, an obviously intoxicated woman drove into a Shell station, seeking to buy gasoline. The station's einployees gave the woinan several cups of coffee over the course of an hour and a

125. See id. at 362-63 (mother, seeking to finance car under her name, indicated to Suburban Motors manager that her son would use.car $25 \%$ of time).

126. See, e.g., Henderson Bros. Stores, Inc. v. Smiley, 120 Cal. App. 3d 903, 174 Cal. Rptr. 875 (1981) (tar kettle); Fuller v. Standard Stations, Inc., 250 Cal. App. 2d 687, 58 Cal. Rptr. 792 (1967) (gasoline).

127. For a discussion of the elements of a common law negligent sale action, see supra text accompanying note 7. In Fuller, the court refused to hold a vendor liable under section 390 of the Restatement (Second) of Torts for selling gasoline to an intoxicated driver because, at that time in California, one could not be held hable even for selling alcohol to an intoxicated driver. Fuller, 250 Cal. App. 2d at 690, 58 Cal. Rptr. at 793-94.

128. 120 Cal. App. 3d at 908, 174 Cal. Rptr. at 877.

129. Id. at 919-20, $174 \mathrm{Cal}$. Rptr. at 884.

130. 202 Cal. App. 3d 151, 247 Cal. Rptr. 663 (ordered not published in California Appellate Reports; opinion appears in California Reporter advance sheets), review denied [no docket number] (Cal. Aug. 18, 1988) (LEXIS, 1988 Cal. LEXIS 220). The court of appeal reversed a summary judgment in favor of the defendants and remanded for jury trial. $247 \mathrm{Cal}$. Rptr. at 671 .

131. Two months after this important decision, pursuant to CAL. R. CT. 976, the court of appeal directed that its June 6, 1988, opimion not be published. The court's order appears at $1988 \mathrm{Cal}$. App. LEXIS 515. 
half. They gave her money to call her mother for a ride and encouraged her not to drive. Nevertheless, the employees sold her gasoline, violating Shell's own policy with respect to drunk drivers. The inebriated woman ignored the employees' advice, proceeded to drive, and collided with a motorcycle, killing its driver and passenger. ${ }^{132}$

The $O$ 'Toole court reasoned that a negligent sale of gasoline, the motive power of an automobile, to an obviously intoxicated driver is indistinguishable from providing alcohol to a drunk driver. ${ }^{133}$ Concern witl preventing drunk driving compelled the conclusion that the station's sale of gasoline to an intoxicated driver was negligent. ${ }^{134}$ Moreover, the court noted, section 390 of the Restatement (Second) of Torts supports the proposition that supplying gasoline to an intoxicated driver is factually equivalent to giving her the car keys. ${ }^{135}$ The court failed to recognize that sellimg goods is substantially different from loaning them. Instead, the court focused on the merchant's "supplying" the intoxicated driver with gasoline. ${ }^{136}$

\section{The Case Against Judge-Made Tort Liability for COMMERCIAL TRANSACTIONS}

A. The Doctrine's Rejection in Florida.

A Florida appellate court, in Vic Potamkin Chevrolet, Inc. v. Horne, ${ }^{137}$ recently became the first to recognize that the expansion of common law liability for negligent commercial transactions could present serious problems for American business. The court also expressly considered whether the theory of negligent entrustment should include a common law action for negligent sales of any product. ${ }^{138}$ Horne, moreover, is the only case to advance economic arguments ${ }^{139}$ in rejecting a

132. O'Toole, 247 Cal. Rptr. at 664.

133. Id. at 669,671 . Framing the argument in this manner, the court easily distinguished Fuller v. Standard Stations, Inc., 250 Cal. App. 2d 687, 58 Cal. Rptr. 792 (1967), which held that furnishing gasoline to an intoxicated driver did not give rise to a cause of action because furnishing even alcohol to such a driver would not support a cause of action under California law at that time. O'Toole, 247 Cal. Rptr. at 665-66. The law in California on serving alcohol to intoxicated drivers has since changed, however. See id. at 666-67.

134. 247 Cal. Rptr. at 671.

135. Id. at 669 .

136. Id. at 670 .

137. 505 So. $2 d 560$ (Fla. Dist. Ct. App. 1987) (en banc), aff'd, No. 70,499, slip op. (Fla. Sept. 1, 1988) (Westlaw, 1988 WL 93694).

138. Id. at 561. For a recent discussion of the appellate court decision, see Note, Who's Driving, Anyway?: The Status of Negligent Entrustment in Florida After Horne v. Vic Potamkin Chevrolet, Inc., 12 Nova L. Rev. 939 (1988).

139. See infra notes $163-65$ and accompanying text. 
negligent sales claim against a merchant. ${ }^{140}$

On its own motion for rehearing en banc in view of the case's exceptional importance, the Florida District Court of Appeal withdrew a panel decision affirming a judgment of $\$ 195,000$ for an injured plaintiff, ${ }^{141}$ and certified the following, yet-to-be-answered, ${ }^{142}$ question to the Supreme Court of Florida:

SHOULD FLORIDA ADOPT SECTION 390 OF THE RESTATEMENT (SECOND) OF THE LAW OF TORTS AND, IF SO, SHOULD THE SECTION BE CONSTRUED SO AS TO EXTEND LIABILITY TO A SELLER OF A CHATTEL AS WELL? ${ }^{143}$

Horne involved a young woman with a restricted driver's license who wanted to purchase an automobile. The license required that the woman drive only in the company of a licensed driver. ${ }^{144}$ The plaintiff, a friend of the buyer, liappened to be in the car lot at the time of the purchase and agreed to accompany the buyer out of tlie lot, altliougli she had never driven witl tlie buyer previously. During an earlier test-drive, the buyer had had difficulty in handling the car; at one point, a salesman had to grab the wlieel to avoid hitting a bus. The salesman later predicted to a fellow employee that the buyer would cause an accident before she drove one block. ${ }^{145}$ His prediction proved accurate. About one mile from the dealership, the buyer lost control of the car and hit a tree, injuring the plaintiff.

The plaintiff sued the dealership for negligently selling an automobile to a driver whom the dealership knew to be incompetent. She argued, in short, "that sellers liave a duty to protect the world against incompetent product users." 146 The full court rejected this assertion, holding that the dealerslip had complied with state law by ensuring that a licensed driver accompanied the buyer from the lot. ${ }^{147}$ The court con-

140. 505 So. $2 d$ at 563 .

141. 505 So. $2 d$ at 561 .

142. The Florida Supreme Court declined to address the broad question certified by the appellate court majority, choosing instead to address the much narrower question offered by the dissent:

IS A SELLER OF AN AUTOMOBILE NEGLIGENT UNDER SECTION 390 OF $R E$ -

STATEMENT (SECOND) OF TORTS (1966) WHEN IT KNOWINGLY SELLS A CAR

TO A DRIVER WHO, AFTER DEMONSTRATING DRIVING INCOMPETENCE,

NEVERTHELESS INTENDS TO DRIVE THE VEHICLE?

Home, No. 70,499, slip op. at 2 \& n.1.

143. 505 So. $2 d$ at 563-64. The court suggested that "if the law is to be extended to include liability for negligent sales, it is for the supreme court or the legislature to do it." $I d$. at 562 .

144. Id. at 561 . The purchaser's license was restricted because she had failed the driving part of the license exam. Id. at 564 (Baskin, J., dissenting).

145. Id. at 564 .

146. Id. at 562 .

147. Id. at 563; see also id. ("The fact that ... the salesman[ ] thought [the customer] was less than competent is simply not relevant."). 
cluded that it is for the state, not merchants, to determine who is qualified to drive, ${ }^{148}$ and that a "seller cannot be held liable for harm caused by a 'defective' customer." 149

The Supreme Court of Florida affirmed the lower court's decision and answered a rephrased certified question in the negative. ${ }^{150}$ The Supreme Court narrowed the question "of great public importance" to the facts of the case and held that a seller of an automobile cannot be held liable under section 390 of the Restatement (Second) of Torts. ${ }^{151}$ The Court relied on three arguments. First, it would be practically impossible to confine the negligent sale cause of action "to instances where the seller becomes aware of the purchaser's incompetency as an incidental by-product of the normal sales routine."152 Instead, to protect themselves from liability, merchants would have to imvestigate each customer's competence; by allowing such a situation to develop, the court would shirk its duty "to foster certamty in business relationships." 153 Second, under Florida law, the transfer of legal and equitable ownership of an automobile terminates the former owner's potential hability. ${ }^{154}$ Third, the adoption of such a broad new public policy as loolding automobile sellers liable for poor selection of customers requires legislative action, since only the legislature can effectively weigh the various interests involved. ${ }^{155}$

The Horne dissent, lowever, was umimpressed by the majority's arguments; it insisted that "[u]nder the Restatement, Potamkin is undoubtedly liable." 156 The dissent claimed that adoption of section 390 "would be a logical, natural progression of the present law of negligent entrustment," 157 and that no policy reason can justify holding hable one who loans automobiles, but not one who sells automobiles. The dissent then echoed the now-familiar dram shop argument that the public needs protection from dangerous drivers ${ }^{158}$ and that the adoption of section 390 is

148. Id.

149. Id. at 562 .

150. Horne, No. 70,499, slip op. at 5. The dissent's rephrased question is quoted supra note 142.

151. Id., slip op. at 1-2. The court admitted that the Restatement (Second) clearly covers sellers and lessors, but the court nevertheless refused to apply negligent entrustment to sales of automobiles. Id. at 4.

152. Id. at 3.

153. Id. (quoting Muller v. Stromberg Carlson Corp., 427 So. 2d 266, 270 (Fla. Dist. Ct. App. 1983)).

154. Id. at 2:3.

155. Id. at 4.

156. Id. at 7 (Kogan, J., joined by Barkett, J., dissenting).

157. Id. at 8.

158. Id. at 8-9. 
therefore "compelling."159 It invoked the shopworn example of a merchant selling a loaded gun to a child. 160

The dissenting opimion seems to support the proposition that a valid driver's license does not necessarily prove competence to buy an automobile. While disclaiming that a conmon law cause of action would give sellers a duty to investigate buyers, the dissent did say that a seller who observes "behavior which indicates an inability to operate an automobile" must dechne to sell to licensed drivers who exhibit sucli behavior. ${ }^{161}$ It failed, lowever, to define what standards of competence a seller, wlio may be a sophisticated automobile dealer or merely a father selling the family car to a son, should apply. Conceivably, newly licensed teenagers, a group obviously inexperienced in driving, would not have the capacity to purchase an automobile under tle dissent's reasoning.

The dissenting opinion also ignores the majority's appreliension that there is no practical way to restrict the Restatement (Second)'s future application to sellers if section 390 is adopted. While admitting that certainty in business is an admirable goal, it asserts that "[c]ertainty in business relationships should not take priority over the safety of our roads and liighways." 162

\section{B. Problems with Judicial Regulation of Commerce.}

The appellate court in Horne recognized the serious commercial ramifications of a duty to protect the public against incompetent users: "The imposition of this new duty not to sell would create uncertainty and retard the free flow of commerce." 163 In addition, the "creation of a duty on the part of the seller to guarantee the acts of a buyer,"164 whicli would effectively require independent mvestigation to establisli each buyer's fitness to use each product, would be "inanifestly unreasonable."165 These sentiments persuaded the Supreme Court of Florida to reject tlie extension of common law liability to merchants who do business with "defective" customers.

Indeed, it would be unreasonable-especially in view of the lack of guidance as to whicli customers are sufficiently experienced or compe-

159. Id. at 8.

160. Id. at 9 .

161. Id.

162. Id.

163. Horne, 505 So. $2 \mathrm{~d}$ at 563 .

164. Id.

165. Id.; see also id. at 563 n.2 ("To extend section 390 to cover negligent sales would effectively convert an arms length commercial relationship into a parental one."); $c f$. Fowler v. Park Corp., 673 S.W.2d 749, 759 (Mo. 1984) (Welliver, J., dissenting); infra text accompanying notes 167-73. 
tent ${ }^{166}$ - to create a duty for merchants not to sell or lease. The uncertainty of the definition of a "defective" customer not only leaves the duty at the heart of the negligent commercial transaction tort open to unlimited expansion; it poses an uncertain risk of liability that businesses might well find too great to assume or insure against.

In a vehement dissent in Fowler v. Park Corp., ${ }^{167}$ discussed above, ${ }^{168}$ a Missouri judge claimed that the majority had given lessors of equipment an unprecedented new duty to actively and continuously investigate the competence of a lessee's employees: "So extraordinary is the duty imposed by the majority today that I can only surmise they fail to comprehend its ramifications. ... [I]t would appear that ... lessors of equipment and other chattel must investigate the qualifications of every employee of the firm acquiring the equipment who may operate it." 169 The judge expressed shock that a court would be willing to create such an amorphous and economically debilitating duty with so little forethought:

It boggles the mind to consider all of the ramifications of this new duty on the leasing industry in this state....

... [T] $]$ he majority creates a theory of negligent entrustment never heretofore contemplated in the law and ... in so doing, they jeopardize the future of the entire leasing and lease-financing industry of Missouri. ${ }^{170}$

This judge seems to have realized that after Fowler, the duty to screen patrons will no longer be limited to transactions regulated by statutes, which provide reasonable and ascertainable guidelines. ${ }^{171}$ Instead, merchants will have to investigate their customers and then sell their products only to those whoin judges will deem competent. ${ }^{172}$ Such judicial regulation of commerce will dramatically alter the way that business has traditionally been conducted in this country, harming the national economy by increasing the cost of producing goods and decreasing sup-

166. See, e.g., Barsness v. General Diesel \& Equip. Co., 383 N.W.2d 840, 844 n.4 (N.D. 1986) (implying that prior accident-free rental of crane to employer may not constitute sufficient "experience" to absolve lessor-begging question of how many prior rentals would constitute "sufficient" experience); $c f$. Henderson Bros. Stores, Inc. v. Smiley, 120 Cal. App. 3d 903, 919-20, 174 Cal. Rptr. 875,884 (1981) (buyer's prior ownership of tar kettle indicated experience, which helped to exonerate defendant-seller from liability for selling the kettle).

167. 673 S.W.2d 749 (Mo. 1984) (en banc).

168. Supra text accompanying notes 103-06.

169. 673 S.W.2d at 759 (Welliver, J., dissenting).

170. $I d$. at 759-60.

171. See, e.g., supra notes 27-29.

172. See Fowler, 673 S.W.2d at 759 (Welliver, J., dissenting). 
ply of goods to consumers. ${ }^{173}$

At a time when lawmakers are struggling to make American mdustries competitive in world markets again, ${ }^{174}$ even minor judicial interference in commerce would be ill-advised. Certainty about potential legal liability is an important component of business relationships. It encourages entrepreneurs to invest new capital in projects, thus promoting economic growth, and it allows established businesses to accurately assess the cost of marketing present and future products. ${ }^{175}$ Unstable, judgemade tort theories can make it more difficult for small businesses to absorb the risk of loss, cripphing their ability to compete with larger businesses on the basis of price. ${ }^{176}$ Moreover, the uncertainty associated with tort hability in the Umited States has recently prompted some European corporations to reconsider domg business with American firms at all. ${ }^{177}$ This response by foreign businesses illustrates the impact that judicial regulation can have on the econoiny.

The judiciary is the branch of government least competent to regulate commerce, either directly or indirectly. ${ }^{178}$ The national economy's sensitivity demands that only legislatures, after weighing competing social concerns, create the duties that underhe hability for negligent commercial transactions.

Holding merchants responsible for the actions of "defective" customers amounts to imposing a fiduciary duty ${ }^{179}$ on an enormous class of

173. See Vic Potamkin Chevrolet, Inc. v. Horne, 505 So. 2d 560, 563 (Fla. Dist. Ct. App. 1987) (en banc) ("sellers would sell fewer products, or they would sell them at a higher cost"), aff'd, No. 70,499 (Fla. Sept. 1, 1988) (Westlaw, 1988 WL 93694).

174. See Ominibus Trade and Competiveness Act of 1988, Pub. L. No. 100-418, 102 Stat. 1107 (sweeping trade bill, intended to enhance competitiveness of American industry).

175. See The Real Tort Conspirators, Wall St. J., Apr. 8, 1988, at 14, col. 1 ("Some moderate predictability in the law is necessary before anyone can assess risks and establish what insurance can cover and how much to charge.").

176. Cf. Saddler, Struggle Looms Over Standards in Liability Law, Wall St. J., Feb. 25, 1988, at 29 , col. 3 (company president supports federal legislation to limit state tort liability after his company was held liable for $\$ 6.2$ million; company lost its insurance and had to lay off 80 workers).

177. See, e.g., CBI to Fight U.S. Liability Ruling. The Times (London), Apr. 28, 1986, at 17, col. 2 (reporting that European companies are finding it difficult to compete in American markets because of excessive tort liability against businesses); Fleet, Nader Charges Unfounded, The Times (London), Jan. 16, 1986, at 19, col. 1 (reporting that Lloyd's of London has lost all confidence in U.S. tort system).

178. See Vic Potamkin Chevrolet, Inc. v. Horne, No. 70,499, slip op. at 4 (Fla. Sept. 1, 1988) (Westlaw, 1988 WL 93694) (quoting Shands Teaching Hosp. \& Clinics, Inc. v. Smith, 497 So. 2d 644, 646 (Fla. 1986), for proposition that judicial branch is the branch least competent to receive public input and resolve broad public pohcy questions).

179. See Meinhard v. Salmon, 249 N.Y. 458, 464, 164 N.E. 545, 546 (1928) (Cardozo, J.) ("Many forms of conduct permissible in a workaday world for those acting at arm's length, are forbidden to those bound by fiduciary ties. A trustee is held to something stricter than the morals of the market place."). 
innocent third parties. ${ }^{180}$ As discussed above, such a fiduciary duty has staggering commercial implications. ${ }^{181}$ When courts have imposed fiduciary obligations on sellers in other contexts, ${ }^{182}$ they have generally defined the obligations narrowly ${ }^{183}$ and have enforced them for the benefit of a limited class of people. ${ }^{184}$ In corporate law, for example, "under certain circumstances and for some purposes the majority stockholders, whether one or many, stand in a fiduciary relation to the corporation and to the minority stockholders." 185 Those majority stockholders are forbidden to sell their interests to "defective" purchasers who they know intend "to loot the corporation's treasury." 186 Selhing to a looter would injure the minority stockholders of the looted corporation, violating the majority's fiduciary duty to those investors. ${ }^{187}$ Although courts have been aggressive in imposing fiduciary obligations in some contexts, ${ }^{188}$ they generally remain cautious in taking steps that would amount to judi-

180. See Horne, 502 So. 2d at $563 \mathrm{n} .2$ (a "parental relationship" would be created); $c f$. Fowler v. Park Corp., 673 S.W.2d 749, 759 (Mo. 1984) (en banc) (Welliver, J., dissenting) ("[I]t would appear that ... lessors of equipinent and other chattel must investigate the qualifications of every einployee of the firm acquiring the cquipment who may operate it.").

181. See id. at 759-60 (future of leasing and lease-financing industry in Missouri will be jeopardized); supra notes 174-77 and accompanyiug text.

182. See, e.g., Swinney v. Keebler Co., 480 F.2d 573, $577-78$ (4th Cir. 1973) (in some circumstances, majority stockholders selling controlling interest in corporation have fiduciary duty to minority stockholders).

183. See, e.g., id. at 578 (With respect to shareholder liability, "the majority is not an absolute insurer against any wrongs which may be done to the corporation after the transfer of control or against any decisions by the new owners that nay not be in the best interest of the minority.").

184. Cf. Pepper v. Litton, 308 U.S. 295, 307 (1939) (For directors and majority shareholders, the "fiduciary obligation is designed for the protection of the entire community of interests in the corporation-creditors as well as stockholders." (footnote omitted and einphasis added)).

185. Gerdes v. Reynolds, 28 N.Y.S.2d 622, 650 (Sup. Ct. 1941); see also Superintendent of Ins. v. Bankers Life \& Casualty Co., 404 U.S. 6, 12 (1971) ("The controlling stockholder owes the corporation a fiduciary obligation ... ."); Swinney, 480 F.2d at 577-78 ("majority stockholders who assume the management of the corporation ... can be said to stand in fiduciary relation to the minority under certain circumstances").

186. Gerdes, 28 N.Y.S.2d at 652; see Swinney, 480 F.2d at 578.

[I] $f$ the sellers of control are in a position to foresee the liketihood of fraud on the corporation ... or on the remaining stockholders ... their fiduciary duty imposes a positive duty to investigate the motives and reputation of the would-be purchaser; and unless sucl a reasonable investigation shows that to a reasonable inan, no fraud is intended or likely to result, the sellers must refrain from the transfer of control.

Id. (citation and footnote omitted).

187. Cf. Swinney, 480 F.2d at 577 (sellers of controlling interests leld hable based on breach of duty not to sell without adequate investigation when circumstances indicated possible fraud) (following Insuranshares Corp. v. Northern Fiscal Corp., 35 F. Supp. 22 (E.D. Pa. 1940)).

188. See, e.g., United States v. Carpenter, 791 F.2d 1024, 1030 (2d Cir. 1986), aff'd, 108 S. Ct. 316 (1987) (noting in insider trading case the importance of enforcing "Congress' stated concern for the perception of faimess and integrity in the securities inarkets and the potential costs of forsaking such legislated concerns, including fewer inarket participants"). 
cial legislation. ${ }^{189}$

\section{CONClusion}

The scope of section 390 of the Restatement (Second) of Torts and its effect on sellers and lessors of nondefective products will be the subject of increasing litigation. To date, few courts have specifically addressed the neghigent commercial transaction tort; even fewer have recognized the potential commercial impact of this judge-made right of action. Most courts have instead focused on adequately coinpensating injured plaintiffs, ignoring the arguinent that a proliferation of neghigent commercial transaction suits against merchants will have detrimental economic effects.

Congress and the state legislatures have the power to regulate the sale of certain goods to specific classes of buyers, ${ }^{190}$ and legislative regulation of alcohol and inherently dangerous products is admittedly in the public interest. Imposing a judge-made duty on sellers to match all kinds of products with "acceptable" consumers, however, harms the industries

189. See, e.g., Schreiber v. Burlington Northern, Inc., 472 U.S. 1, 12 (1985) (In determining meaning of "manipulative" under §14(e) of the Securities Exchange Act of 1934, 15 U.S.C. $§ 78 \mathrm{n}(\mathrm{e})$ (1982), the legislative purpose is controlling because "[i]nviting judges to read the term 'manipulative' with their own sense of what coustitutes 'unfair' or 'artificial' conduct would inject uncertainty iuto the tender offer process."); $c f$. Cannon v. University of Chicago, 441 U.S. 677, 718 (1979) (Rehnquist, J., concurring) (noting, in civil rights context, that "this Court in the future should be extremely reluctant to imply a cause of actiou absent such specificity on the part of the Legislative Branch").

In the coutext of SEC Rule 10b-5, 17 C.F.R. $\$ 240.10 b-5$ (1988), the Supreme Court, in Blue Chip Stamps v. Manor Drug Stores, 421 U.S. 723 (1975), considered whether to extend a private cause of action under the Rule to a stock offeree "in connection with the purchase or sale of any security." 17 C.F.R. $§ 240.10$ b-5 (1988). The majority declined to do so. 421 U.S. at 755 . In a concurring opimion, Justice Powell opposed broadening sellers' cominon law hability to offerees, citing many of the same economic cousiderations that weigh against inposing judge-Inade duties on merchants of chattels:

the courts already have inferred a private cause of action that was not authorized by the legislation. . . . If such a far-reaching change is to be inade, with unpredictable consequences for the process of raising capital so necessary to our economic well-being, it is a inatter for the Congress, not the courts.

Id. at 759-60 (Powell, J., concurring).

Justice Powell understood that commercial liability affects a wide range of interests, and that courts should allow legislatures to balance the concerns of undercompensated, sympathetic plaintiffs with the needs of our frec-market economy.

190. See, e.g., U.S. CoNST, art. I, §8, cl. 3 ("The Congress shall have Power ... To regulate Commerce ... ."); MASS. CONST. pt. 2, ch. 1, art. IV, $\S 1$ (state legislature has full power and authority to make laws "for the good and welfare of this commonwealth"); TEX. CONST. art. $3, \S 1$ ("The Legislative power of this State shall be vested in a Senate and House of Representatives (...."). 
that the courts decide to regulate. ${ }^{191}$ Fewer goods will be produced, and they will be sold to consumers at higher prices. Moreover, small businesses will find it difficult to compete with large competitors who can more easily absorb the added risk of liability. In some markets, this risk may create a formidable barrier to entry for small busmesses, harmmg competition.

The future direction of the negligent commercial transaction tort is unclear. However, under the sweeping language of cases like Dillon, Barsness, and Fowler, actions might conceivably be brought against an aircraft supplier on behalf of crash victims for the sale of passenger aircraft to an airline with a "poor" safety record, or agamst a passenger train supplier for leasing coaches to an operator with a recent history of train accidents.

In Horne, the Supreme Court of Florida considered econo1mic principles that had previously been ignored in the debate over the neghigent commercial transaction tort's scope. American industries that feel that jurists cannot or will not adequately address their interests when creatimg amorphous new duties will welcome Horne's new approach. As the Horne court has recognized, the legislature is the brancli of government best qualified to balance society's interests when an issue involves substantial economic impact. The judicial restraint of the Florida Supreme Court in Horne should serve as a model to other states forced to consider the proper scope of section $\mathbf{3 9 0}$ of the Restatement (Second) of Torts witl respect to the sellers and lessors of nondefective goods.

Robert M. Howard

191. See Horne v. Vic Potamkin Chevrolet, Inc., No. 70,499, slip op. (Fla. Sept. 1, 1988) (Westlaw, 1988 WL 93694) (automobile industry); Fowler v. Park Corp., 673 S.W.2d 749, 759 (Mo. 1984) (en banc) (Welliver, J., dissenting) (leasing industry). 